\title{
Souvenir d'ltalie. La vocazione inclusiva del disegno visionario
}

\author{
Paolo Belardi
}

Abstract

Capacità d'accoglienza, capacità d'integrazione e capacità di adattamento: tre qualità distintive delle città europee che, essendosi sviluppate come luoghi vocati alle ibridazioni etniche, hanno sempre saputo adattarsi alle emergenze abitative succedutesi nel corso dei secoli. Anche quando si è trattato di stravolgere i monumenti più identitari. Basti pensare all'anfiteatro romano di Nîmes, al palazzo imperiale di Spalato e alla basilica paleocristiana di Salamina, convertiti in altrettanti super-condomini volti ad accogliere rispettivamente i perseguitati dalle campagne punitive di Carlo Martello, i superstiti delle scorribande degli Avari e i pellegrini in visita alla tomba di San Barnaba. E noi Italiani, proprio perché viviamo in città cresciute su se stesse nel segno della continuità, siamo particolarmente predisposti a concepire nuovi modelli abitativi, ancorché transitori, volti ad accogliere le popolazioni immigrate (a prescindere dal fatto che siano costituite da migranti, profughi o rifugiati) costruendo sopra, sotto, dentro, intorno e accanto all'esistente. Questo il senso di un progetto, come Souvenir d'Italie (presentato da Hoflab in occasione della mostra La città dell'inclusione, allestita a Roma negli spazi del MACRO Asilo dal 9 al 10 novembre 2019), che è profondamente radicato nel codice genetico del Belpaese, perché è composto da nove soluzioni tipologiche sorprendenti, che evocano le architetture più pittoresche delle città italiane e che sono veicolate mediante altrettante simulazioni infografiche volte a rivendicare, non senza un'evidente vena provocatoria, la vocazione inclusiva del disegno visionario italiano.

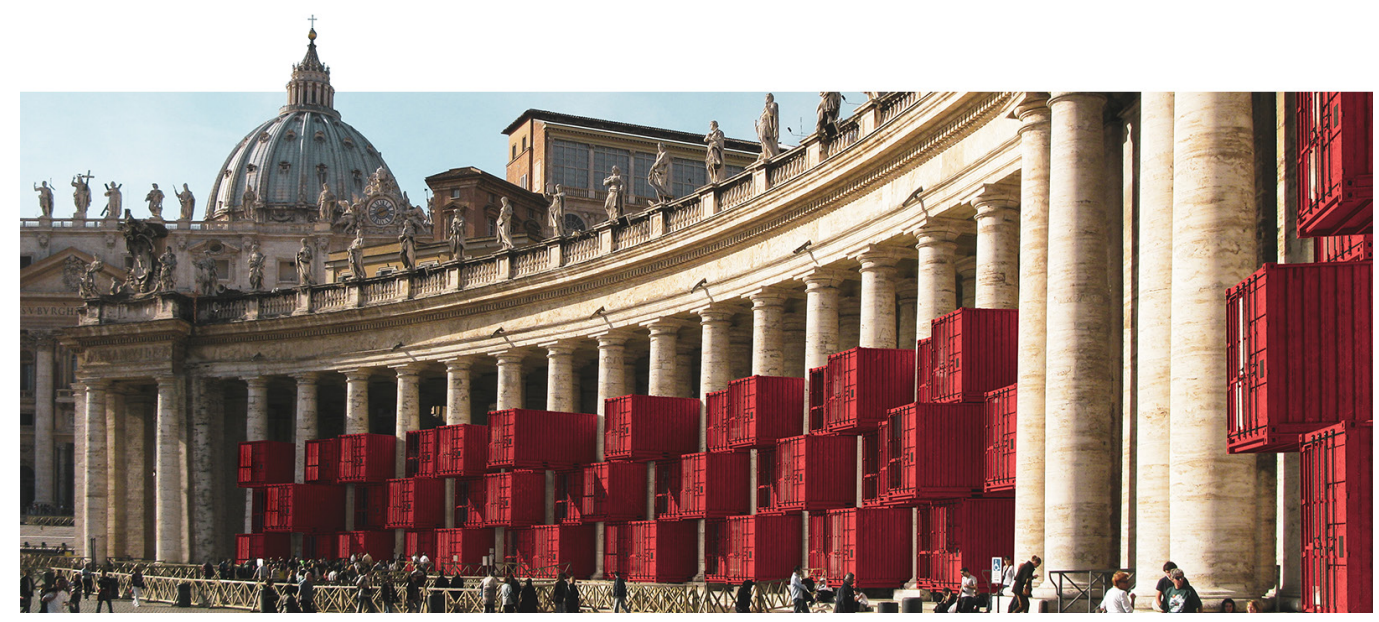




\section{II disegno inclusivo}

"Nel vasto, molteplice e misterioso territorio del disegno, includere significa inserire nel campo grafico un certo numero di elementi simili o diversi l'uno nell'altro. Tale operazione compositiva, che ha un che di magnetico, owvero che acquista un tono gravitazionale, crea un sistema organico di interrelazioni e di interferenze. Le varie identità degli elementi si mescolano e si ibridano scambiandosi caratteri e segni. Ciò avviene anche quando l'inclusione si verifica tra elementi uguali modulati su dimensioni variabili. Tutto ciò implica che essa è una forma d'accoglienza che, mentre acquisisce l'altro, modificandosi, fa anche sì che tale metamorfosi sia logica, evidente e durevole" [Purini 2009, p. 94].

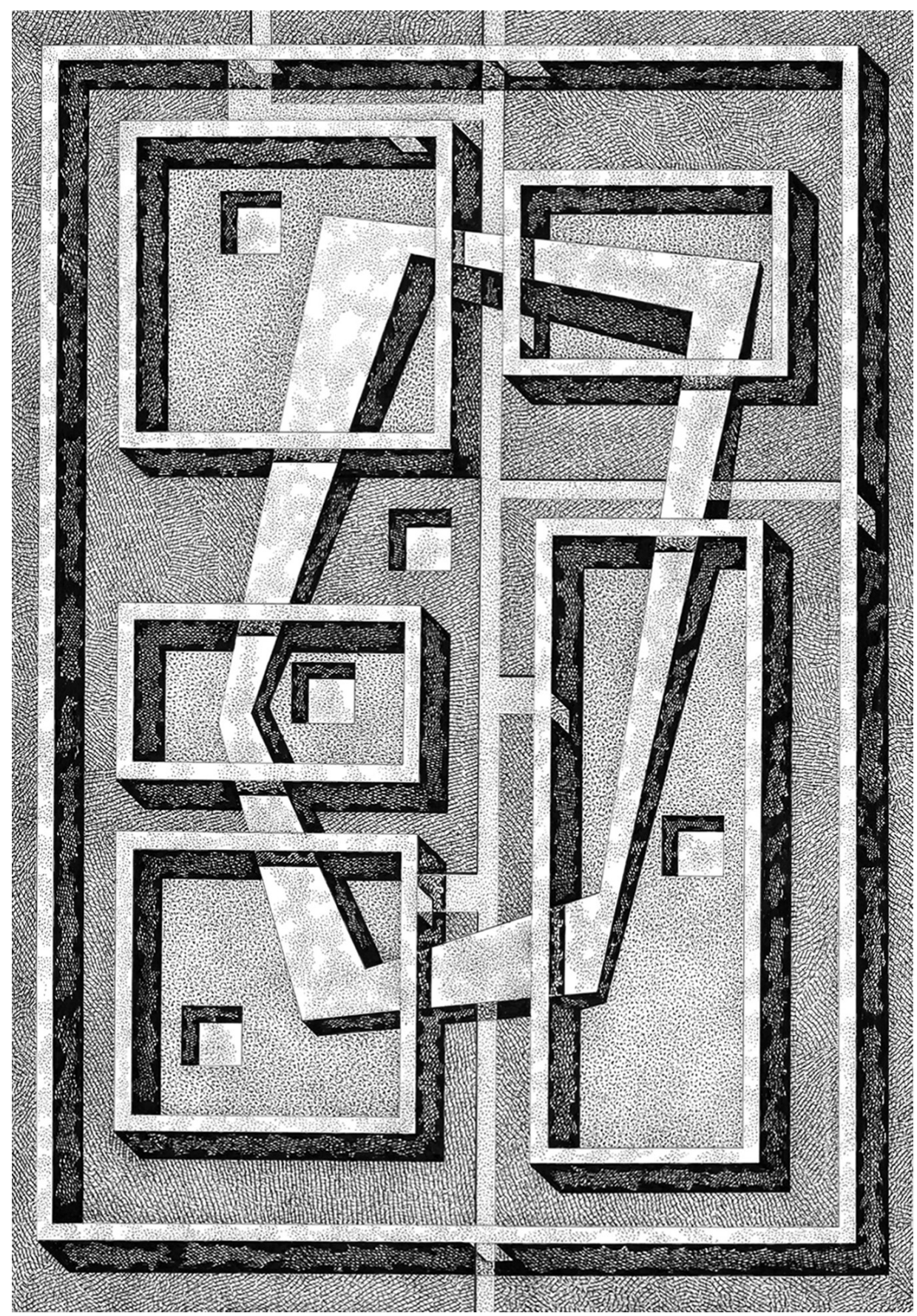




\section{Gli esseri umani sono sempre stati una specie migrante}

Gli esseri umani sono sempre stati una specie migrante [Pievani 20 I 6]. Per questo i massicci spostamenti delle popolazioni che negli ultimi anni, partendo dalle periferie del mondo (Afghanistan, Messico, Siria, Sud Sudan ecc.), si sono mosse e continuano tuttora a muoversi verso le grandi metropoli confidando in migliori prospettive di vita non possono e non devono sorprendere. Non a caso, dopo che i primi esseri umani, circa 200.000 anni fa, si sono spostati dal Sud Africa al Nord Africa e quindi, circa 60.000 anni fa, hanno intrapreso la colonizzazione del globo terrestre spingendosi fino alla punta del Sud America, si sono susseguiti ripetuti fenomeni migratori [Cohen 2019; Sheller, Urry 2006]: dalle invasioni barbariche (166-476) alle trasmigrazioni mongole (1206- |259), dalla tratta atlantica degli schiavi ( $170 \mid$ - | 810$)$ all'emigrazione transatlantica dall'Europa verso gli Stati Uniti d'America (|8|5-19|4), dall'esodo della popolazione irlandese conseguente alla Great Hunger (I8451850) alla diaspora ebraica provocata dall'avvento del regime nazista (1933-1940) fino alla disseminazione dei boat people vietnamiti nel Sud-Est asiatico (1975-1995). Ciò che invece può e deve sorprendere è il fatto che i fenomeni migratori recenti, invece di essere interpretati come occasioni di crescita sociale e di rinnovamento urbano, sono stati rigettati a priori e sono stati additati come causa scatenante della crisi identitaria che affligge l'Europa [I]. Mentre la storia c'insegna che sono state proprio le grandi migrazioni dell'antichità a smussare le differenze genetiche consentendo la formazione di un'unica specie umana disseminata su tutto il pianeta. Così come c'insegna che la bellezza delle città europee in generale, e di quelle italiane in particolare, è derivata proprio dalla loro capacità di governare virtuosamente i processi d'integrazione e di scambio tra le componenti culturali eterogenee succedutesi nel corso dei secoli, includendo nel proprio tessuto la presenza di più comunità sociali, di più lingue parlate e di più stili architettonici che, contaminandosi reciprocamente, ne hanno sempre riflesso la molteplicità civile [Rossi 1978].

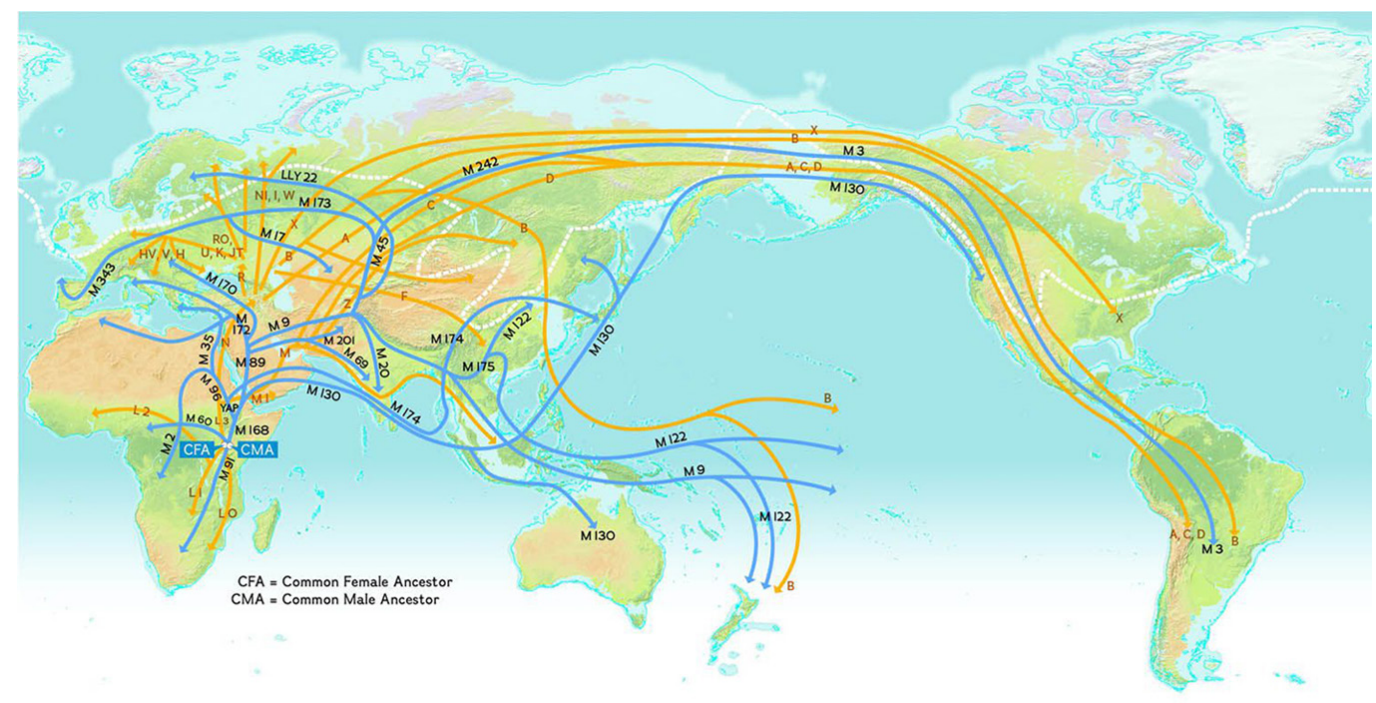

\section{L'accoglienza è uno dei fondamenti della civiltà europea}

L'accoglienza è uno dei fondamenti della civiltà europea. Così come è evidenziato a livello linguistico, visto che "la radice del vocabolo latino hospes si trova in hostis (lo straniero che gode degli stessi diritti del popolo romano), a sua volta derivante dall'indoeuropeo ghostis, da cui anche host e guest in inglese, e gast in tedesco" [Agostini 2017, p. 69]. Tanto che la voce italiana 'ospite', indicando al contempo ospitato e ospitante, tradisce la reciprocità di un patto d'accoglienza da sempre sacro. Ė noto infatti che presso le civiltà arcaiche il rifiuto 
dell'accoglienza era considerato un atto sacrilego, così come è noto che i Greci credevano che gli dèi potessero presentarsi in incognito come ospiti, distribuendo ricompense o punizioni in base al comportamento del padrone di casa. Ma è altrettanto noto che, con l'affermazione della cristianità come religione di stato, l'accoglienza dei poveri e degli emarginati è diventata una forma d'istituzionalizzazione del mandato evangelico, serrata in un nodo borromeo con quella degli ordini religiosi e delle vie di pellegrinaggio, lungo i cui tracciati, durante l'età medievale, si sono addensati gli 'xenodochia' e gli 'hospitalia' [Mazzi 2000; Beltramo, Cozzo 20 I3; Franco 20 I7] (edifici quadrangolari, organizzati intorno a una o più corti interne, che hanno trovato un'espressione compiuta nella Ca' Granda, realizzata a Milano nella seconda metà del XV secolo a partire da un progetto del Filarete). Due tipologie edilizie straordinariamente innovative, elette non a caso a 'cattedrali dell'accoglienza', che hanno anticipato la tipologia illuminista dei reclusori, vocata ad accogliere cittadini disagiati, nel cui novero risaltano l'Albergo dei Poveri di Genova, realizzato su progetto di Stefano Scaniglia, il Reale Albergo dei Poveri di Palermo, realizzato su progetto di Orazio Furetto poi ripreso da Giuseppe Venanzio Marvuglia e Nicolò Puglia, e il Reale Albergo dei Poveri di Napoli, realizzato solo parzialmente su progetto di Ferdinando Fuga. Ma soprattutto il ruolo fondamentale svolto dall'accoglienza nell'ambito della formazione delle città europee è riscontrabile nella capacità di affrontare le emergenze abitative succedutesi nel corso dei secoli modificando le proprie regole morfologiche in funzione delle ibridazioni etniche indotte dai flussi migratori. Peraltro sempre e comunque costruendo nel costruito, anche quando si è trattato di stravolgere i monumenti più identitari. Basti pensare ai casi esemplari dell'anfiteatro romano di Nîmes e del palazzo imperiale di Spalato, convertiti in altrettante cittadelle fortificate per accogliere rispettivamente i perseguitati dalle campagne punitive di Carlo Martello e i superstiti delle scorribande degli Avari [2].

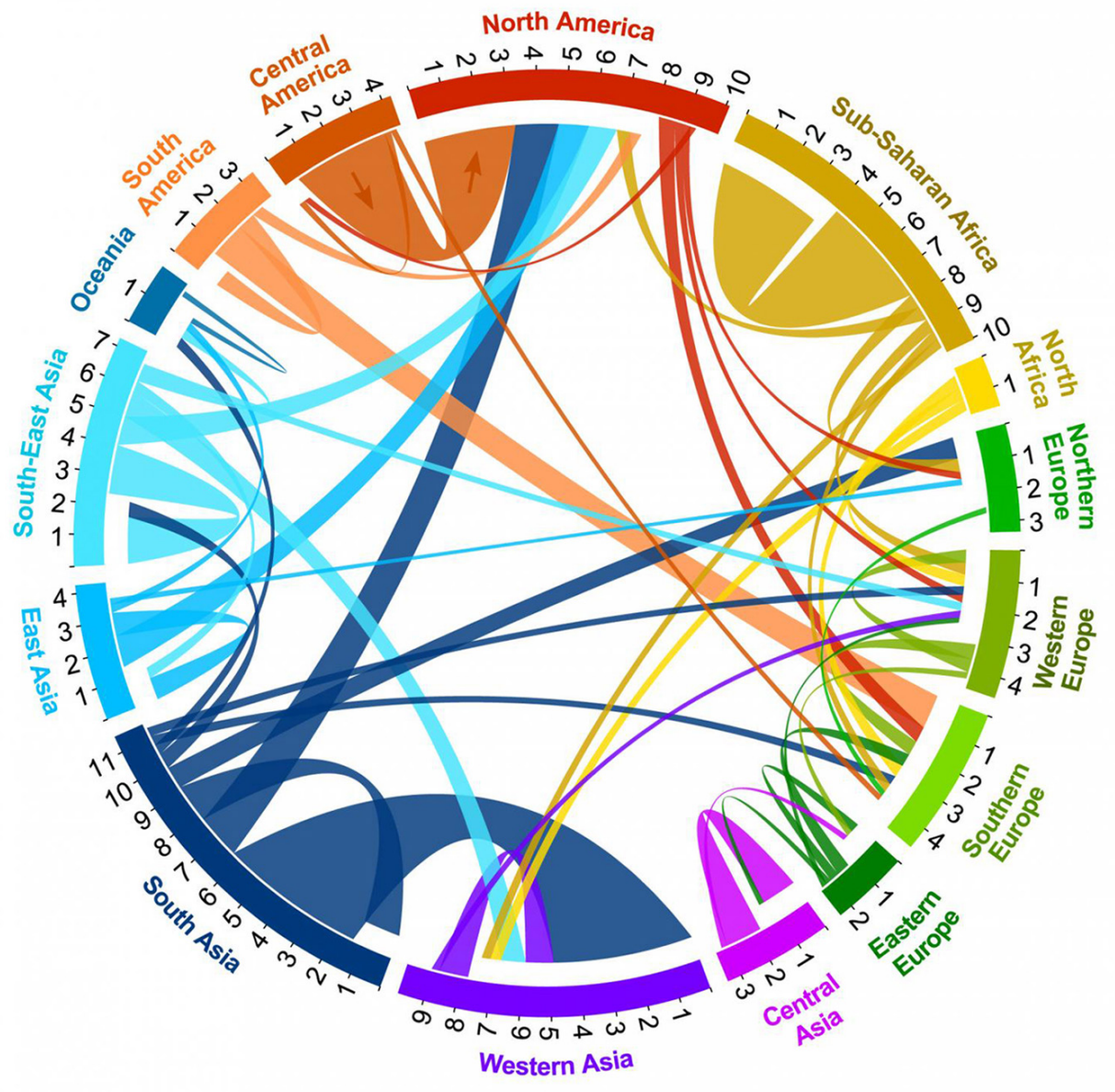




\section{In Europa i flussi migratori recenti sono stati caratterizzati dalla discontinuità}

In Europa i flussi migratori recenti sono stati caratterizzati dalla discontinuità [Melotti 2004; Bettin, Cela 20 I4]. Tanto che sono riconoscibili almeno tre fasi. La prima fase (1945-1973) è stata segnata tanto da migrazioni intercontinentali quanto da migrazioni continentali, laddove le migrazioni intercontinentali sono state indotte dai 'fattori di espulsione' presenti nelle nazioni di esodo, tra cui gli effetti delle grandi crisi politiche ed economiche che hanno accompagnato il processo di decolonizzazione. Mentre le migrazioni continentali, oltre che ai fattori di espulsione presenti nelle nazioni di esodo (di ordine demografico, economico, sociale, culturale e in parte anche politico, come nel caso della Spagna, del Portogallo, della Grecia e della Jugoslavia), sono state indotte dai fattori di attrazione delle nazioni di approdo, tra cui il richiamo dall'Europa meridionale all'Europa settentrionale di manodopera a basso costo per la ricostruzione post-bellica. La seconda fase (1973-1982) ha avuto inizio con la crisi economica scatenata dall'embargo petrolifero e, con essa, con l'esaurimento della funzione trainante delle attività produttive che avevano caratterizzato il boom economico degli anni Sessanta. In questa fase, venute meno le migrazioni continentali, è ripresa la pressione dei flussi migratori intercontinentali, spesso e volentieri clandestini perché provenienti da nazioni devastate da tensioni sociali e da conflitti civili anche molto cruenti (dall'Argentina al Cile, dall'Etiopia allo Sri Lanka). La terza fase (1982-2020) è stata avviata dalla ripresa economica dalla crisi degli anni Settanta e, seppure tra le alterne vicende della congiuntura economica e dell'impatto di avvenimenti storici epocali (dal crollo del muro di Berlino agli attentati alle Torri Gemelle di New York fino alla crisi economica iniziata nel 2008), è tuttora in corso ed è contrassegnata da un'intensificazione dei flussi migratori imputabile ai fattori espulsivi delle nazioni d'esodo. Soprattutto in Africa dove, venute meno le speranze e le illusioni della decolonizzazione e dell'indipendenza politica, sono sopravvenute una crisi economica e una disgregazione sociale che, incrudelite da conflitti oltremodo cruenti, spingono alla fuga crescenti masse di giovani, disposti ad affrontare ogni rischio pur di allontanarsi da una vita senza prospettive. Così come confermano le continue tragedie che affliggono quanti cercano di attraversare prima il deserto del Sahara e poi il mare Mediterraneo con mezzi di trasporto inadeguati, perché vecchi e sovraffollati, oltre che fuorilegge, perché gestiti da vere e proprie organizzazioni criminali.

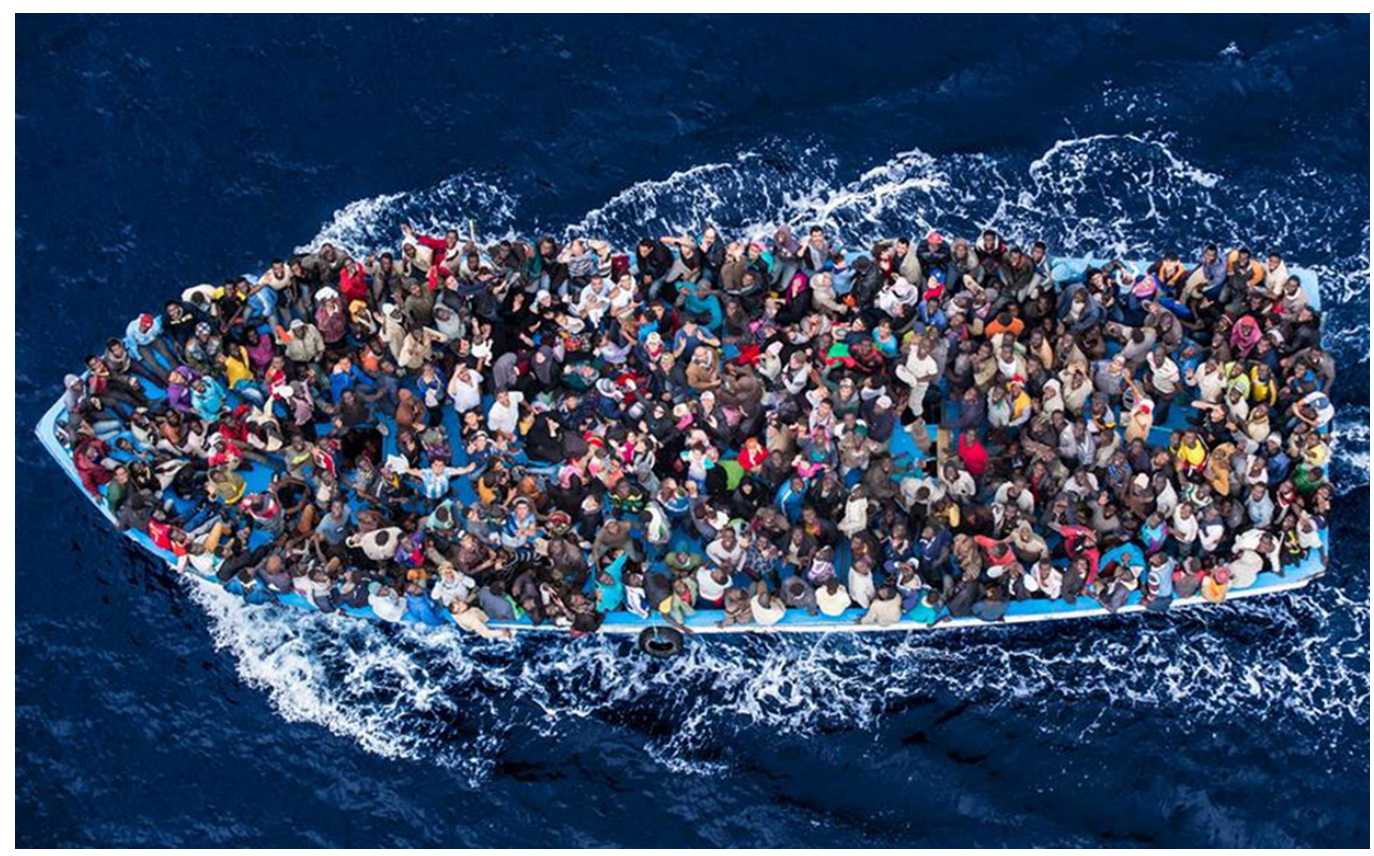




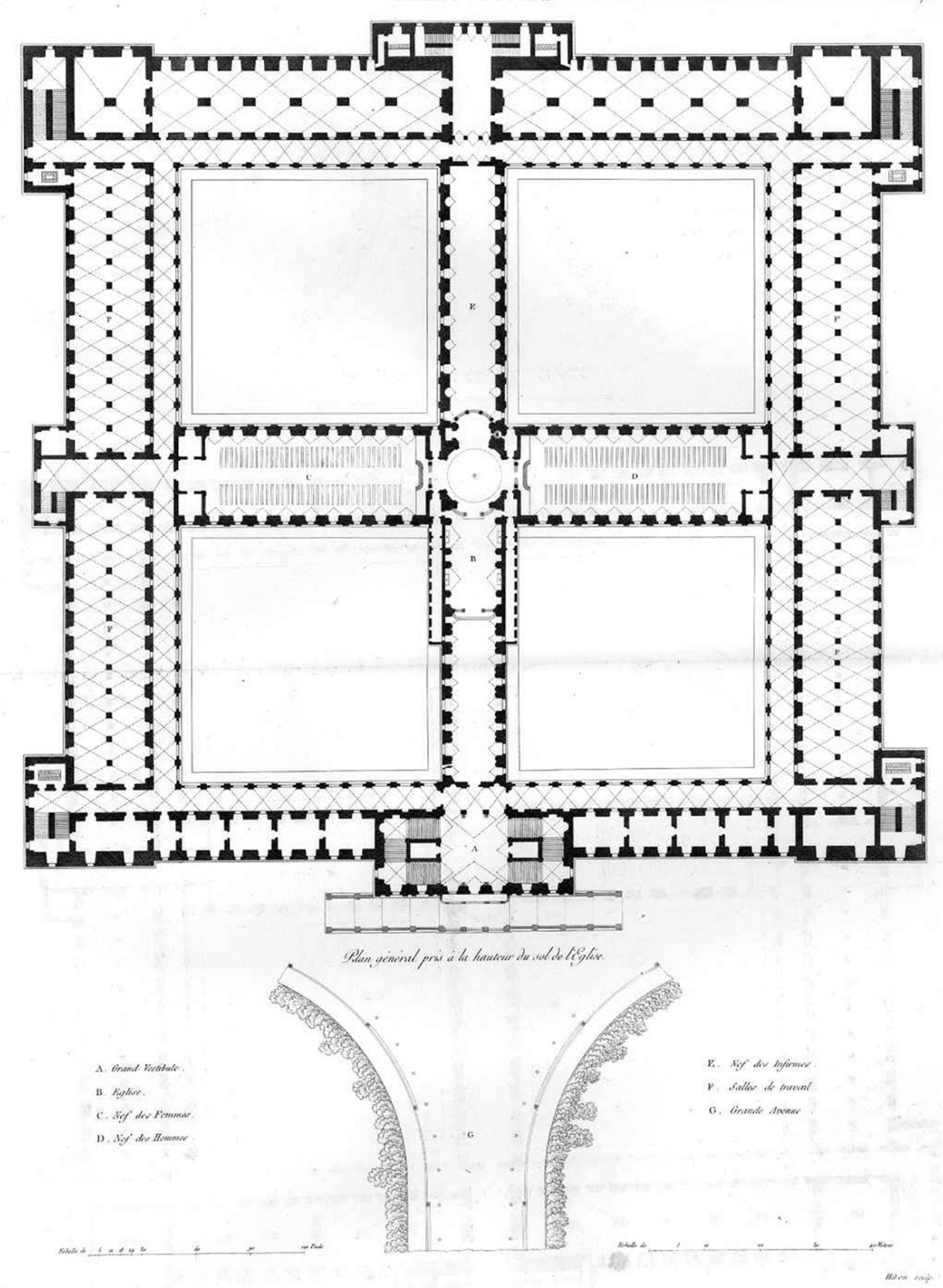




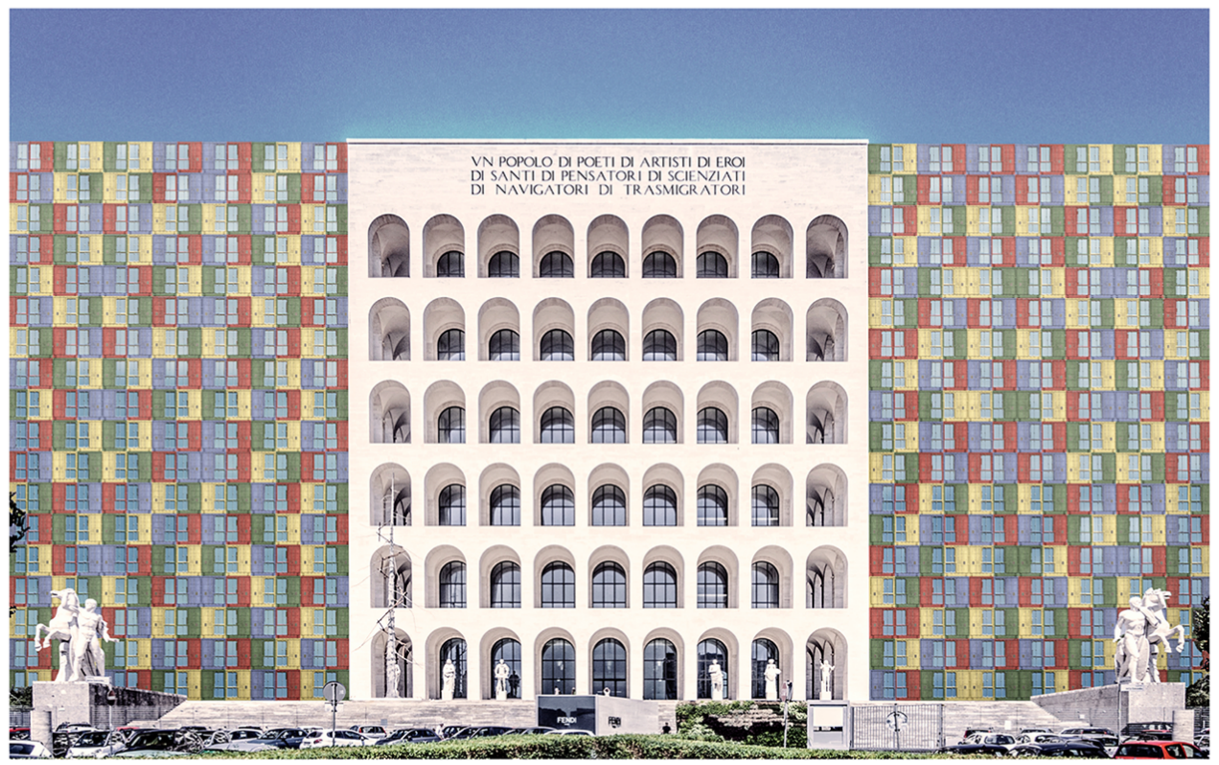

saluti da Rama

Ma chere Pauline,
je suis setourne en Palie apris beaucoup diannées
et j'ai éte fascine par la créativite et la ginérosite avec lesquelles limergence d accucillir nos fieres immigrants a éte resolve, en donnant vic aux villes les plus inclusives quejaic jamais vnes... Aliles Ataliens! ton Bernard

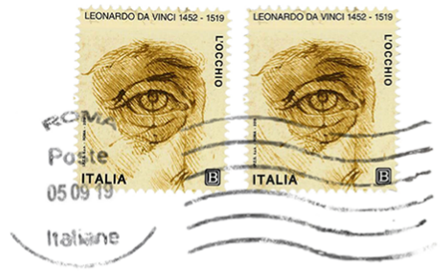

$\frac{\text { Pauline Piop }}{\frac{23 \text {, we de la Pipublique }}{12500-\text { Dakas }}}$ 
Fig. 7. Souvenir d'Italie: Verona, Caserta, Mila

Fig. 8. Souvenir d'Italie: Venezia, Matera, Firenze Salemi, Hoflab, 2019.
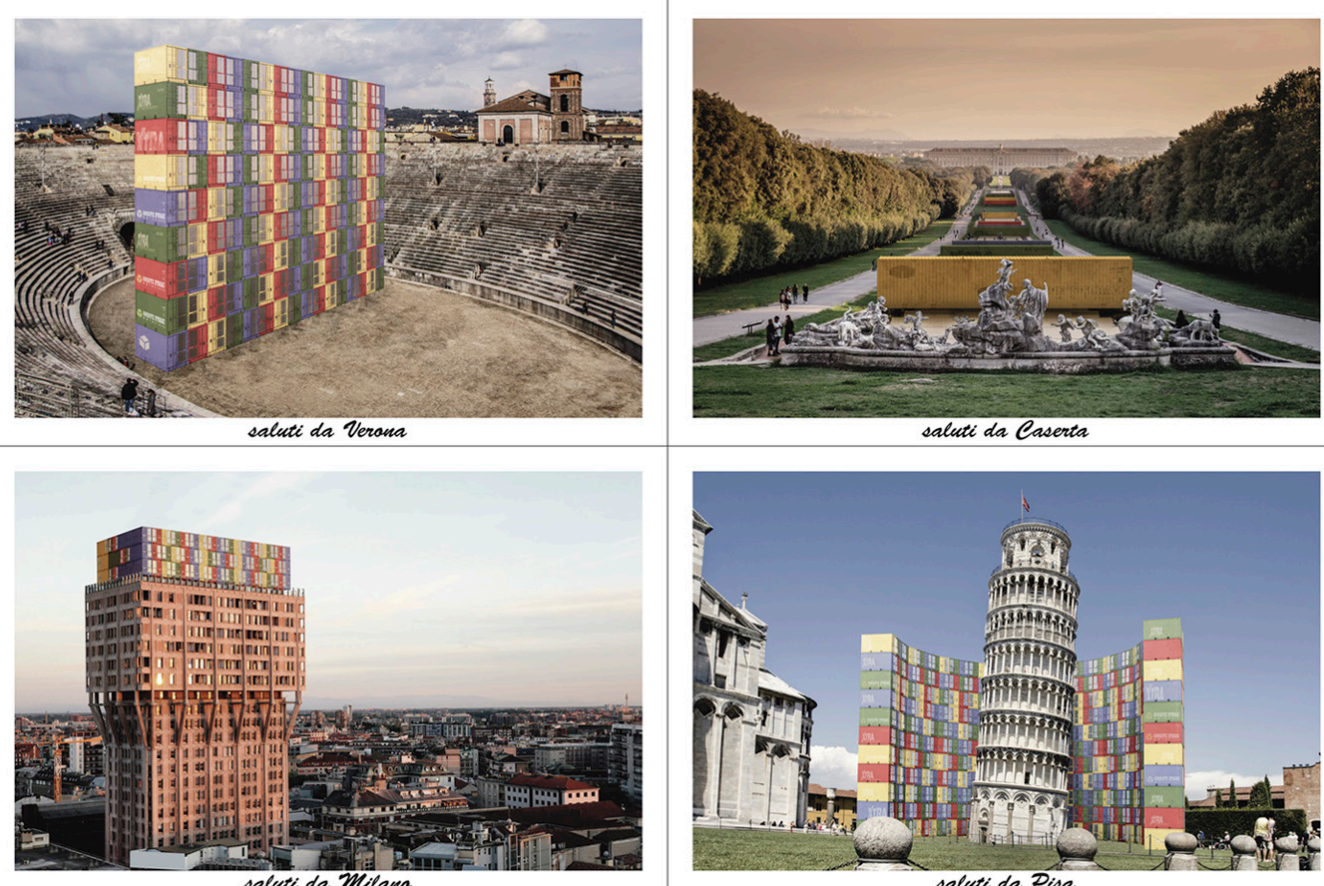

saluti da Milana
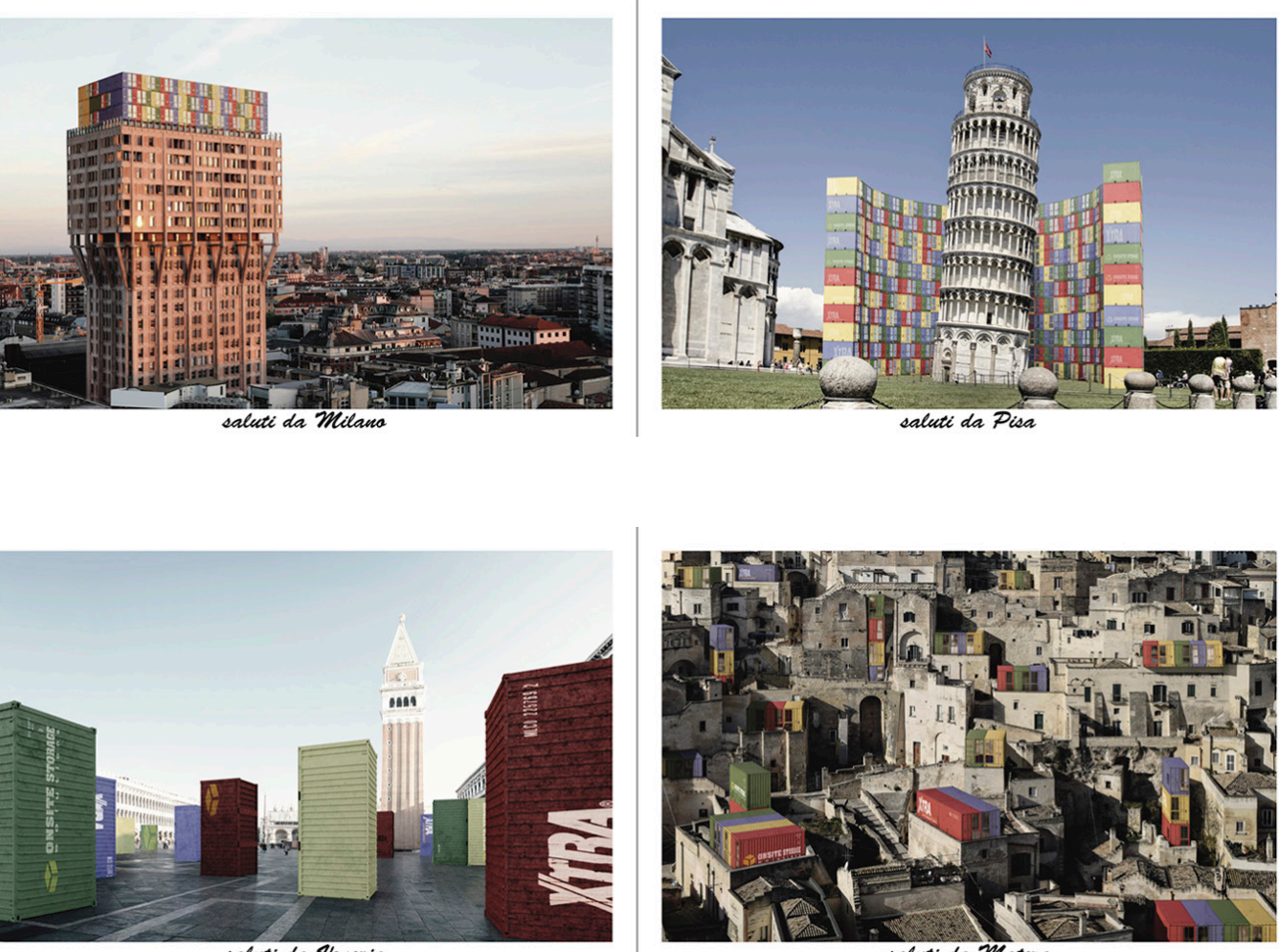

saluti da Venezia

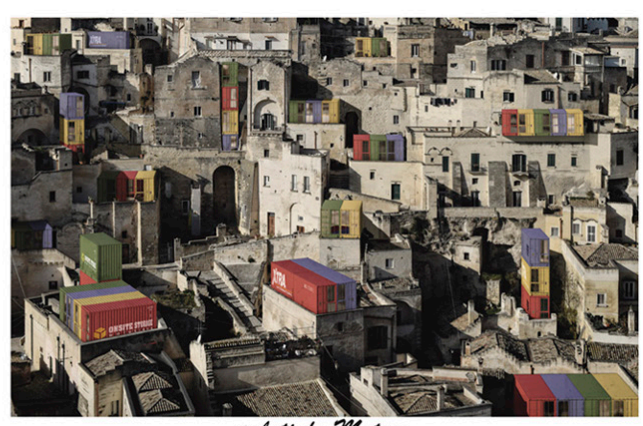

saluti da Matera
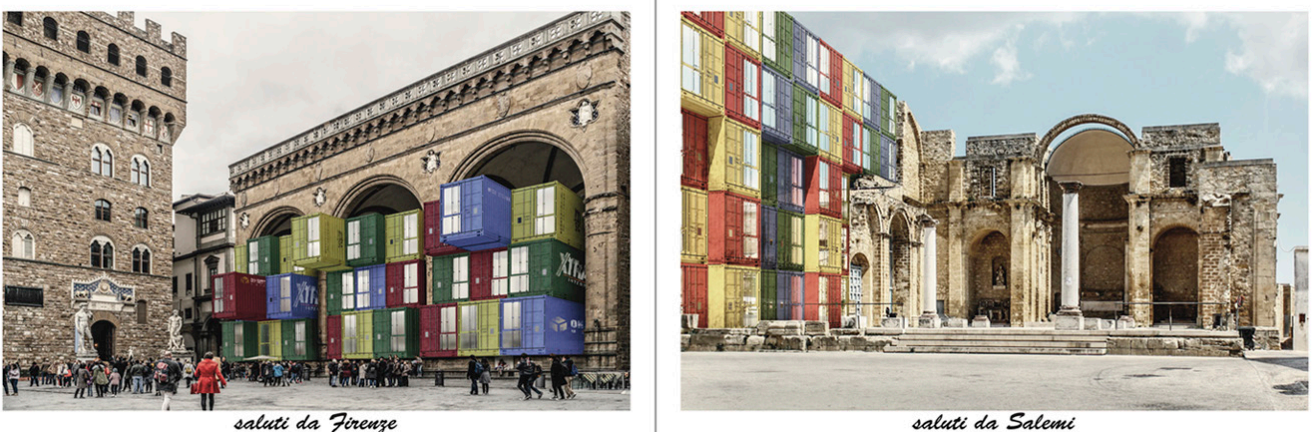


\section{I flussi migratori hanno sempre generato nuovi spazi}

I flussi migratori hanno sempre generato nuovi spazi. $\bigcirc$ comunque hanno generato il ripensamento degli spazi esistenti introducendo i germi fecondi di una cultura abitativa alternativa. Anche e soprattutto in Italia [Abdelmalek 2002; De Maria, Lagravinese 20 I5; Cossu 20। 8-20 I9, p. 28; De Micco 20 I6-20 I7]. È evidente infatti che, pur essendo l'integrazione un concetto ambivalente e multidimensionale, che coinvolge aspetti antropologici, culturali, economici e sociali, è proprio l'integrazione abitativa a comportare le problematiche più complesse e quindi più impegnative. Sia perché la forte percentuale di immigrati clandestini favorisce la proliferazione di veri e propri ghetti in cui è segregata una buona parte della manodopera a basso costo impiegata in agricoltura nelle attività stagionali di lavorazione e raccolta. Sia perché le aree in cui tendono a convergere gli immigrati regolari, anche a causa delle discriminazioni che orientano il mercato immobiliare, sono per lo più marginali e presentano alcune caratteristiche comuni in quanto si formano in parti degradate ed abbandonate dagli autoctoni, in cui il costo degli alloggi è molto basso e spesso sono luoghi in cui è possibile plasmare lo spazio abbandonato secondo i propri modi di vita. Ciò che ne consegue è un fenomeno di esclusione abitativa che serra in un tutt'uno il concetto di integrazione con quello di pari opportunità e che alimenta un mercato parallelo, costituito da un patrimonio immobiliare costituito da edifici altrimenti non abitabili in base alla normativa italiana vigente in materia [Tosi 2000, p. 320; Tosi 1994]. Mentre le strutture di accoglienza, in base alle raccomandazioni emanate dallo SPRAR-Sistema di protezione per richiedenti asilo e rifugiati istituito dal Ministero dell'Interno della Repubblica Italiana, "devono comunque es-

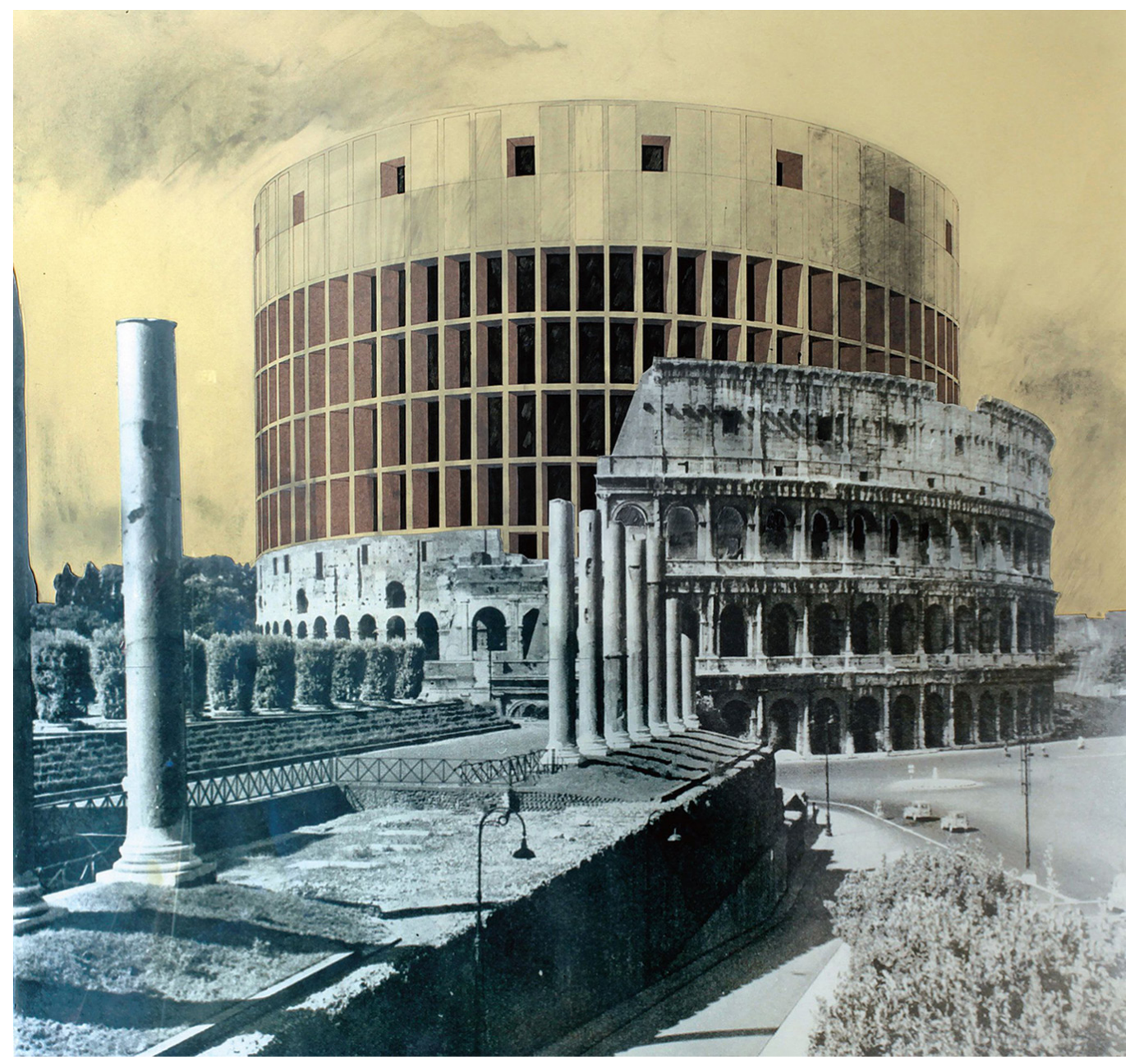


sere in possesso dei requisiti previsti dalle norme vigenti in materia di urbanistica, di edilizia, di prevenzione incendi, di igiene e di sicurezza. [...] La struttura di accoglienza deve essere dotata di servizi igienici adeguati e in numero sufficiente in rapporto ai beneficiari accolti (minimo I ogni 6), nonché proporzionalmente superiore in base al numero di beneficiari e alla presenza mista di genere. Le stanze - sempre dotate di finestre aperte all'esterno - devono essere in numero proporzionale alle persone accolte (massimo 4 persone per stanza in centri collettivi; 2 o 3 persone negli appartamenti). Ma soprattutto "per non ostacolare la partecipazione alla vita sociale e l'accesso ai servizi del territorio da parte dei beneficiari è importante che la struttura di accoglienza sia collocata in luoghi abitati, facilmente raggiungibili da servizi di trasporto pubblico" [SPRAR 20 I8, pp. 32, 33].

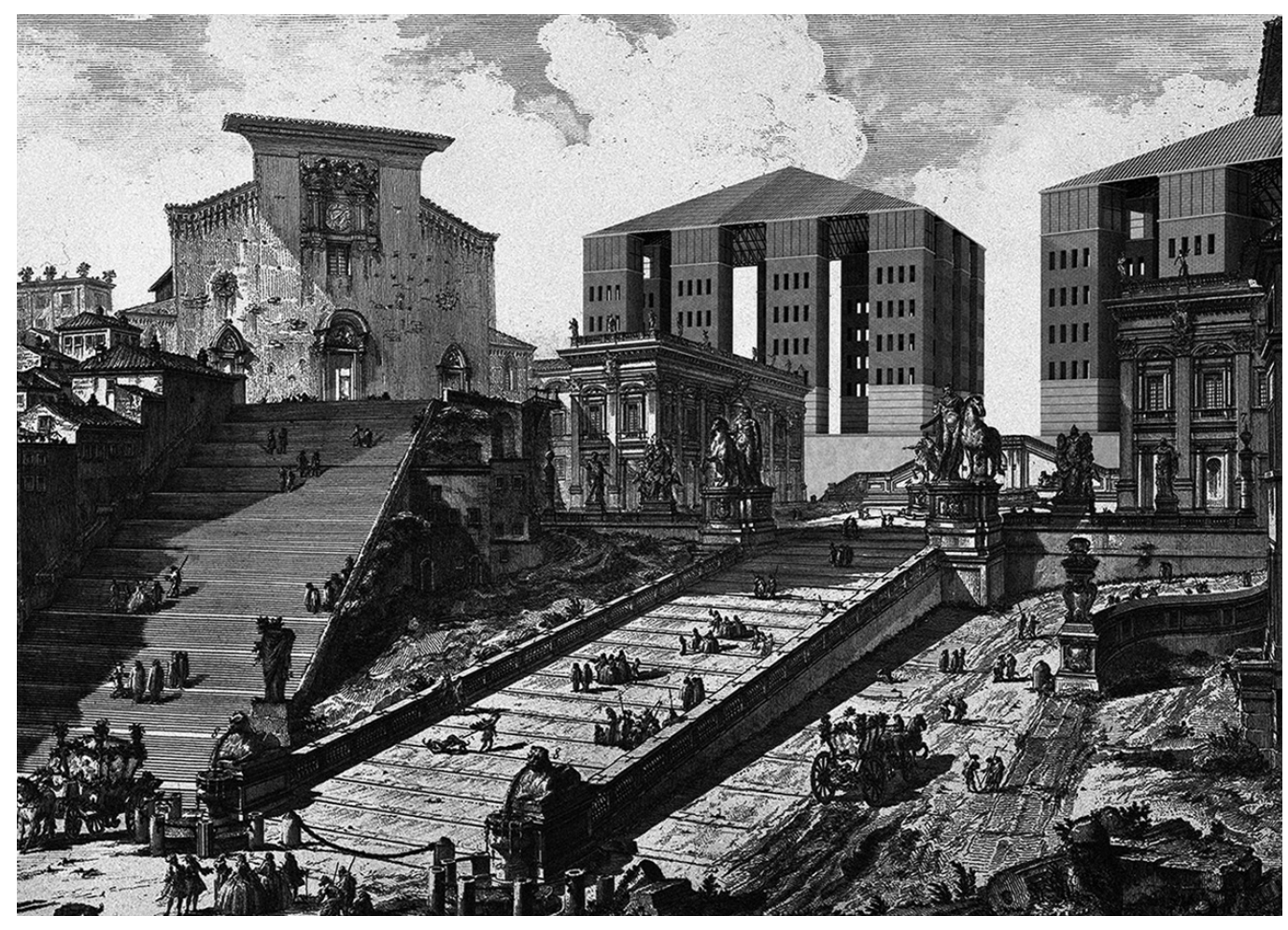

\section{In futuro l'Italia sarà un paese multirazziale o, se preferite, colorato}

In futuro l'Italia sarà un paese multirazziale o, se preferite, colorato. Al pari dell'Europa [Eco 2017, p. 26]. E noi Italiani, proprio perché viviamo in città cresciute su se stesse nel segno della continuità, siamo particolarmente predisposti a concepire nuovi modelli abitativi, ancorché transitori, volti ad accogliere le popolazioni immigrate (a prescindere dal fatto che le stesse siano costituite da migranti, profughi o rifugiati) costruendo sopra, sotto, dentro, intorno e accanto all'esistente. Questo il senso del progetto Souvenir d'Italie, presentato da Hoflab nell'ambito della mostra La città dell'inclusione, allestita a Roma negli spazi del MACRO Asilo dal 9 al 10 novembre 2019, in cui sono prefigurate nove possibili soluzioni abitative per l'accoglienza illustrate in forma di cartoline turistiche e contrassegnate dall'innesto di veri e propri villaggi pop-up sui monumenti più identitari del nostro paese: dall'arena di Verona alla reggia di Caserta, dalla torre Velasca di Milano alla torre pendente di Pisa, dalla piazza San Marco di Venezia al quartiere Sassi di Matera, dalla loggia dei Lanzi di Firenze all'ex chiesa Madre di Salemi. Fino al palazzo della Civiltà del Lavoro di Roma, inglobato tra due supercondomini composti con un'iterazione di container policromi: una 


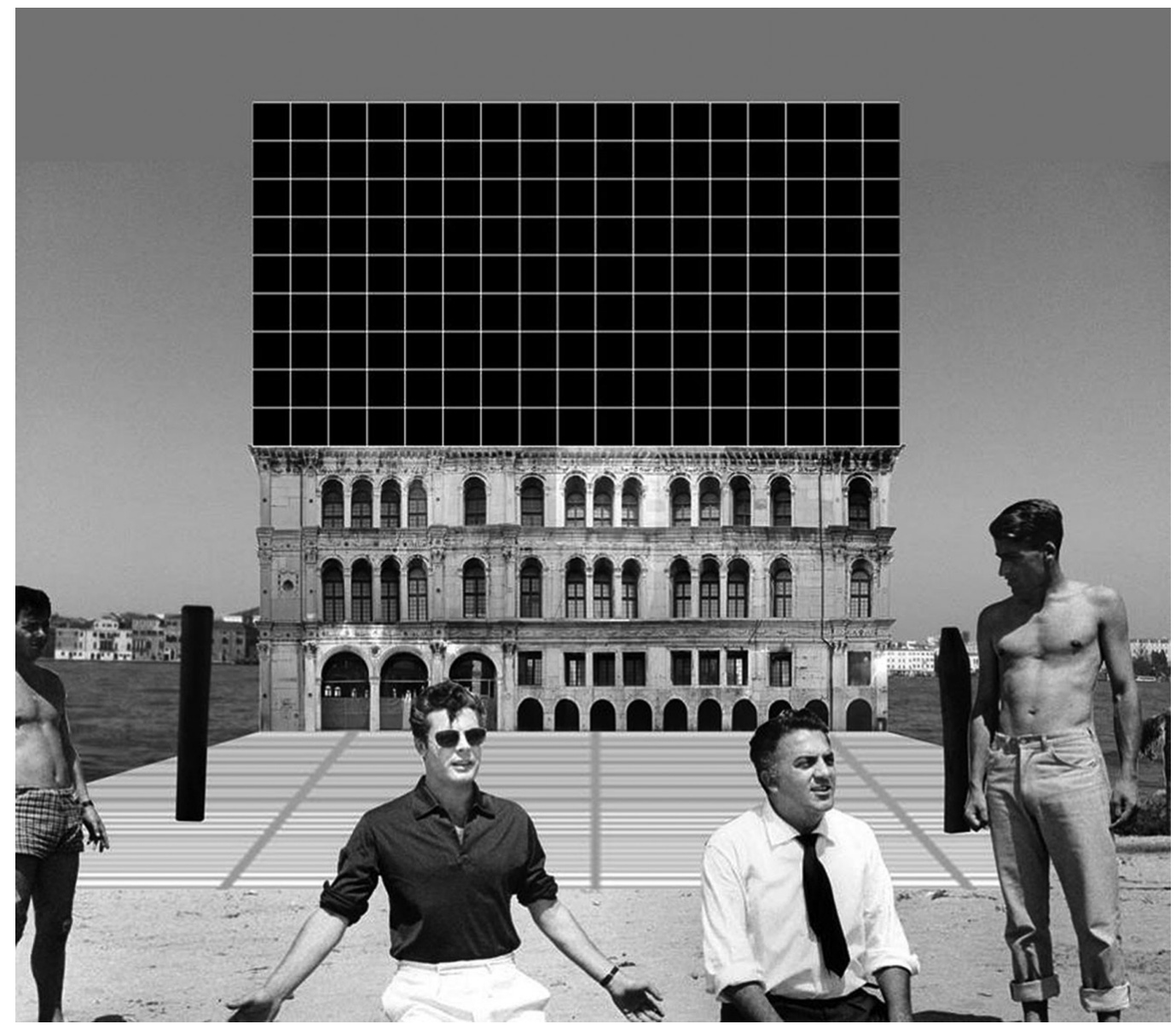

Fig. 12. Supernapoli,

Cherubino Gambardella,

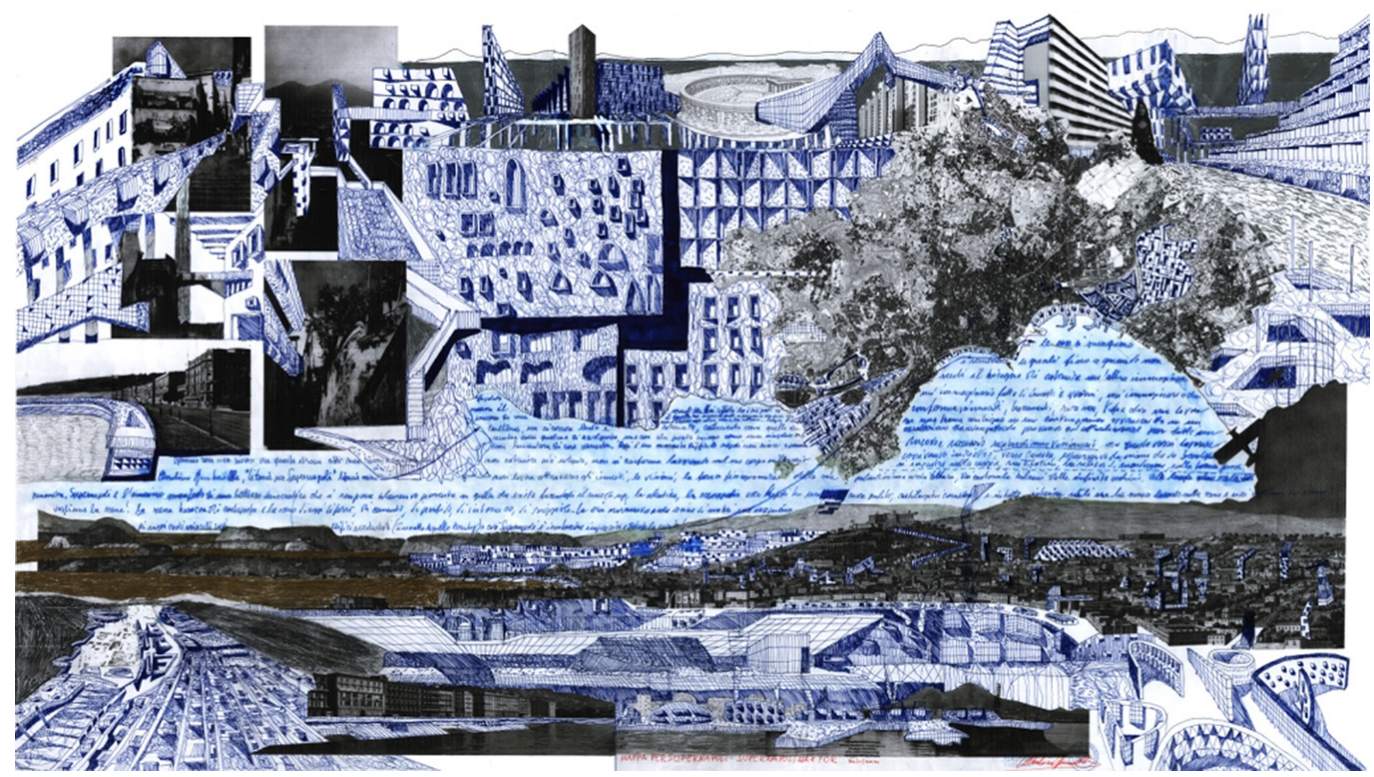


soluzione tipologica talmente ardita da lasciare basito Bernard, l'immaginario artista francese che, colpito da tanta creatività (oltre che da tanta generosità), scrive di getto una cartolina alla moglie senegalese." Ma chère Pauline, je suis retourné en Italie après beaucoup d'années et j'ai été fasciné par la créativité et la générosité avec lesquelles l'émergence d'accueillir nos freres immigrants a été résolue, en donnant vie aux villes les plus inclusives que j'aie jamais vues ... Ah, les Italiens!' ' Hoflab 20 I 9, p. 43] Nove soluzioni tipologiche sorprendenti, che evocano le architetture più pittoresche delle nostre città (dal palazzo della famiglia Savelli, costruito sulle vestigia del teatro romano di Marcello, alle case dei pescatori di Atrani, incuneate negli arconi della strada costiera borbonica) e che sono veicolate mediante altrettante simulazioni infografiche volte a rivendicare, con un intento provocatorio programmatico, la vocazione inclusiva del disegno visionario, anche nei casi più intricati quali proprio i centri storici italiani in generale e il centro storico di Roma in particolare (dal Grand Hotel Colosseo del Superstudio alla Veduta di Piazza del Campidoglio di Leon Krier, dal Palazzo Veneziano di Carmelo Baglivo alla Supernapoli di Cherubino Gambardella). D'altra parte, così come registrato con lucidità da Franco Purini, includere significa "inserire un certo numero di elementi simili o diversi l'uno nell'altro [...] - che - crea un sistema organico di interrelazioni e di interferenze" [Purini 2019, p. 94]: tanto nel disegno dell'architettura quanto nell'architettura della città. Ovvero significa restituire all'utopia, attraverso la pratica del disegno visionario, il suo diritto di esistere.

\section{Note}

[I] “L'integrazione deve essere uno scambio reciproco di esperienza umana sul piano psicologico, deve essere uno scambio culturale dal quale emerga una prospettiva più ampia e matura e deve essere un inserimento dell'immigrato nella nuova struttura sociale come una parte vitale e funzionale che arricchisce l'insieme" [Alberoni, Baglioni 1965, p. 26]. Si veda anche: Hoerder 2002; Hatton, Williamson 2005.

[2] "Ma a livello urbano non ho qui illustrato il caso di Spalato, che a mio avviso costituisce, non un esempio eccezionale, ma certamente il più probante. Cioè quello di un grande edificio, un palazzo, che diventa città e trasforma i suoi caratteri interni in caratteri urbani dimostrando la ricchezza infinita delle trasformazioni analogiche nell'architettura quando questa opera su forme precise" [Rossi 1978, p. 244].

\section{Riferimenti bibliografici}

Abdelmalek Sayad (2002). La doppia assenza. Dalle illusioni dell'emigrato alle sofferenze dell'immigrato. Milano: Raffaello Cortina.

Agostini llaria (20 17). Per civica pietà. Architettura dell'accoglienza nella città medievale (V-XV secolo). In Agostini llaria, Attili Giovanna, Decandia Lidia et al. La città e l'accoglienza. Castel San Pietro Romano (Rm): La Talpa, pp. 69-98.

Alberoni Francesco, Baglioni Guido (1965). L'integrazione dell'immigrato nella società industriale. Bologna: II Mulino.

Beltramo Silvia, Cozzo Paolo (a cura di). (20I3). L'accoglienza religiosa tra tardo antico ed età moderna: luoghi, architetture, percorsi. Roma:Viella Libreria Editrice.

Bettin Giulia, Cela Eralba (20।4). L'evoluzione storica dei flussi migratori in Europa e in Italia. Venezia: Università IUAV di Venezia.

Bonifazi Corrado (2007). L'immigrazione straniera in Italia. Bologna: II Mulino.

Cohen Robin (2019). Migration. London: André Deutsch Limited.

Colombo Asher, Sciortino Giuseppe (a cura di). (2002). Stranieri in Italia: assimilati ed esclusi. Bologna: II Mulino.

Colombo Asher, Sciortino Giuseppe (2004). Gli immigrati in Italia. Bologna: II Mulino.

Cossu Edoardo (2018-2019). Spaces for Migrant Reception in the Municipalities of Basso Campidano. Torino: Politecnico di Torino. Decimo Francesca, Sciortino Giuseppe (a cura di). (2006). Reti migranti. Bologna: II Mulino.

De Maria Marcello, Lagravinese Raffaele (2015). II disagio abitativo dei migranti in Italia. Best practices per una società migliore. Bari: Università degli Studi di Bari Aldo Moro.

De Micco Lorenzo Emilio (20 I6-20 17). Architettura dell'accoglienza. Le implicazioni spaziali della crisi migratoria raccontati attraverso la digital fabbrication. Milano: Politecnico di Milano.

Eco Umberto (2019). Migrazioni e intolleranza. Milano: La nave di Teseo.

Franco Elena (2017). Hospitalia o sul significato della cura. Torino: Artema. 
Hatton Timothy J., Williamson Jeffrey G. (2005). Global Migration and the World Economy. Cambridge USA: MIT Press.

Hoerder Dirk (2002). Cultures in Contact. Durham USA: Duke University Press.

Hoflab (2019). Souvenir d'Italie. In Messina Francesco, Zerella Laura (a cura di). La città dell'inclusione. Spoleto (Pg): ADD-art, pp. $42-43$.

Mazzi Maria Serena (2000). I viaggi dei poveri e degli emarginati. In Gensini Sergio (a cura di). Viaggiare nel Medioevo. Ospedaletto (Pi): Pacini Editore, pp. 317-336.

Melotti Umberto (1994). L'immigrazione in Italia: da modello senza progetto a progetto senza modello. Un confronto con altri paesi europei. In Annali di Sociologia/Soziologisches Jahrbuch, 10, 1994, pp. 21 I -232.

Melotti Umberto (2004). Migrazioni internazionali: globalizzazione e culture politiche. Milano: Bruno Mondadori Editore

Natale Marcello, Strozza Salvatore (1997). Gli immigrati stranieri in Italia. Quanti sono, chi sono, come vivono?. Bari: Cacucci.

Pievani Telmo (20 I6). Migranti, da due milioni di anni. In Micron, n. 34, pp. 2 I-25.

Pugliese Enrico (2002). L'Italia tra migrazioni internazionali e migrazioni interne. Bologna: II Mulino

Purini Franco (2019). Includere. In Messina Francesco, Zerella Laura (a cura di). La città dell'inclusione. Spoleto (Pg): ADD-art, 2019, pp. 94, 95.

Rossi Aldo (1978). L'architettura della città. Milano: Clup.

Sheller Mimi, Urry John (2006). The new mobilities paradigm. In Environment and Planning A: Economy and Space, n. 38, pp. 207-226.

SPRAR (20 I 8). Manuale operativo per l'attivazione e la gestione di servizi di accoglienza e integrazione per richiedenti e titolari di protezione internazionale e umanitaria. Roma: Ministero dell'Interno Italiano.

Tosi Antonio (1994). Abitare/coabitare. Gli immigrati extracomunitari e le politiche abitative in Italia. In Tosi Antonio (a cura di). Abitanti. Le nuove strategie dell'azione abitativa. Bologna: II Mulino, pp. 29-40.

Tosi Antonio (2000). Casa e immigrazione. In Zincone Giovanna (a cura di). Primo rapporto sull'integrazione degli immigrati in Italia. Bologna: II Mulino, pp. $317-354$.

\section{Autore}

Paolo Belardi, Università degli Studi di Perugia, paolo.belardi@unipg.it

Per citare questo capitolo: Belardi Paolo (2020). Souvenir d'ttalie. La vocazione inclusiva del disegno visionario/Souvenir d'Italie. The Inclusive Vocation of Visionary Drawing. In Arena A., Arena M., Brandolino R.G., Colistra D., Ginex G., Mediati D., Nucifora S., Raffa P. (a cura di). Connettere. Un disegno per annodare e tessere. Atti del $42^{\circ}$ Convegno Internazionale dei Docenti delle Discipline della Rappresentazione/Connecting. Drawing for weaving relationships. Proceedings of the 42th International Conference of Representation Disciplines Teachers. Milano: FrancoAngeli, pp. 889-914. 


\title{
Souvenir d'ltalie. The Inclusive Vocation of Visionary Drawing
}

\author{
Paolo Belardi
}

Abstract

The capacity to welcome, to integrate and to adapt: these are three distinctive qualities of European cities which, having developed as places suited to ethnic hybridisation, have always been able to adapt to the housing emergencies that have occurred over the centuries, even when it comes to repurposing the most representative monuments. Just think of the Roman amphitheatre in Nimes, the Imperial Palace in Split or the early Christian basilica in Salamis, converted into equally grand apartment buildings aimed at welcoming, respectively, those persecuted by Charles Martel's punitive campaigns, the survivors of the Avar raids and pilgrims to the tomb of Saint Barnabas. Precisely because we Italians live in cities that have evolved in the sign of continuity, we are particularly predisposed to conceiving new, albeit transitory, housing models aimed at welcoming immigrant populations (regardless of whether they are migrants or refugees), building above, below, inside, around and beside existing structures. This is the meaning of a project such as Souvenir d'Italie (presented by Hoflab on the occasion of the exhibition La citta dell'Inclusione (The Inclusive City), held in Rome in the spaces of the MACRO Asilo from 9th to I0th November 2019), which is deeply rooted in the genetic code of the Belpaese. Composed of nine surprising typological solutions, it evokes the most picturesque architecture of Italian cities conveyed through similarly photorealistic simulations, aimed at vindicating the inclusive vocation of visionary Italian drawing, with a clear provocative vein.

Keywords

migration, reception, drawing, project, utopia.

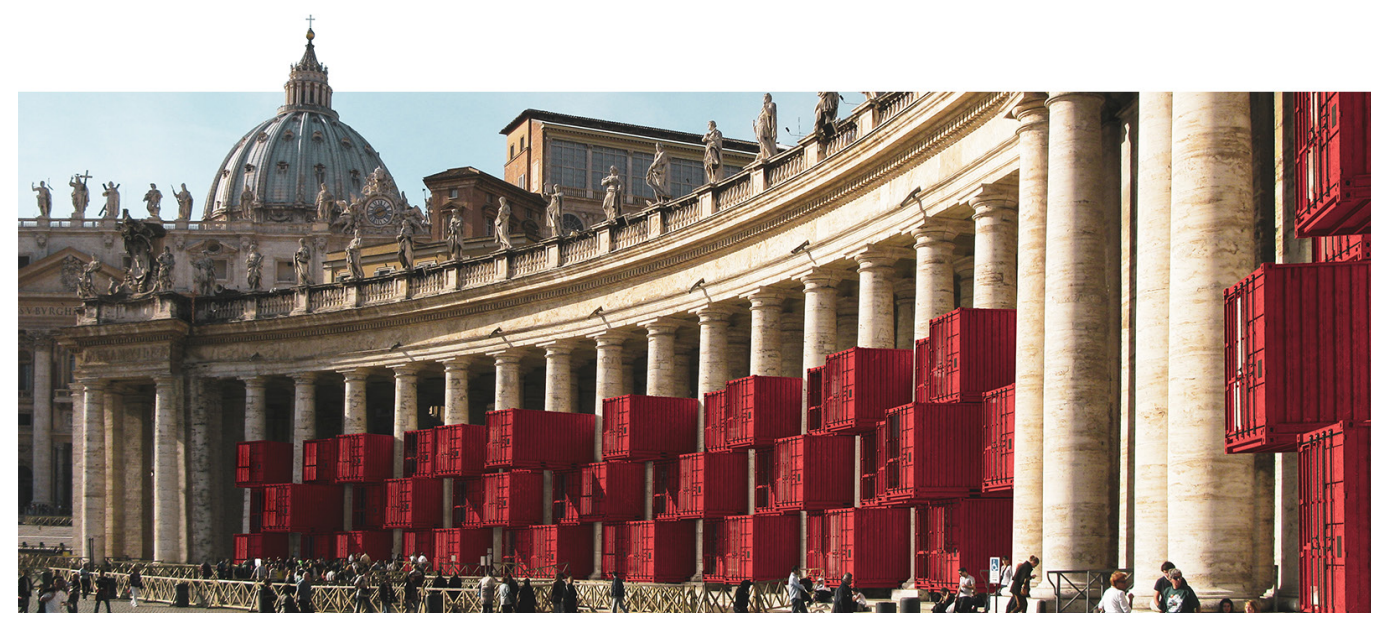




\section{Inclusive drawing}

"In the vast, multiple and mysterious territory of drawing, to include means to insert a certain number of elements similar or different from each other in the graphic field. This compositional operation, which has a magnetic aspect, that is, which acquires a gravitational tone, creates an organic system of interrelationships and interferences. The various identities of the elements mix and hybridise, exchanging characters and signs. This also happens when the inclusion occurs between equal elements modulated on variable dimensions. All this implies that it is a form of reception which, while acquiring the other, modifying itself, also causes this metamorphosis to be logical, evident and lasting"' [Purini 2009, p. 94].

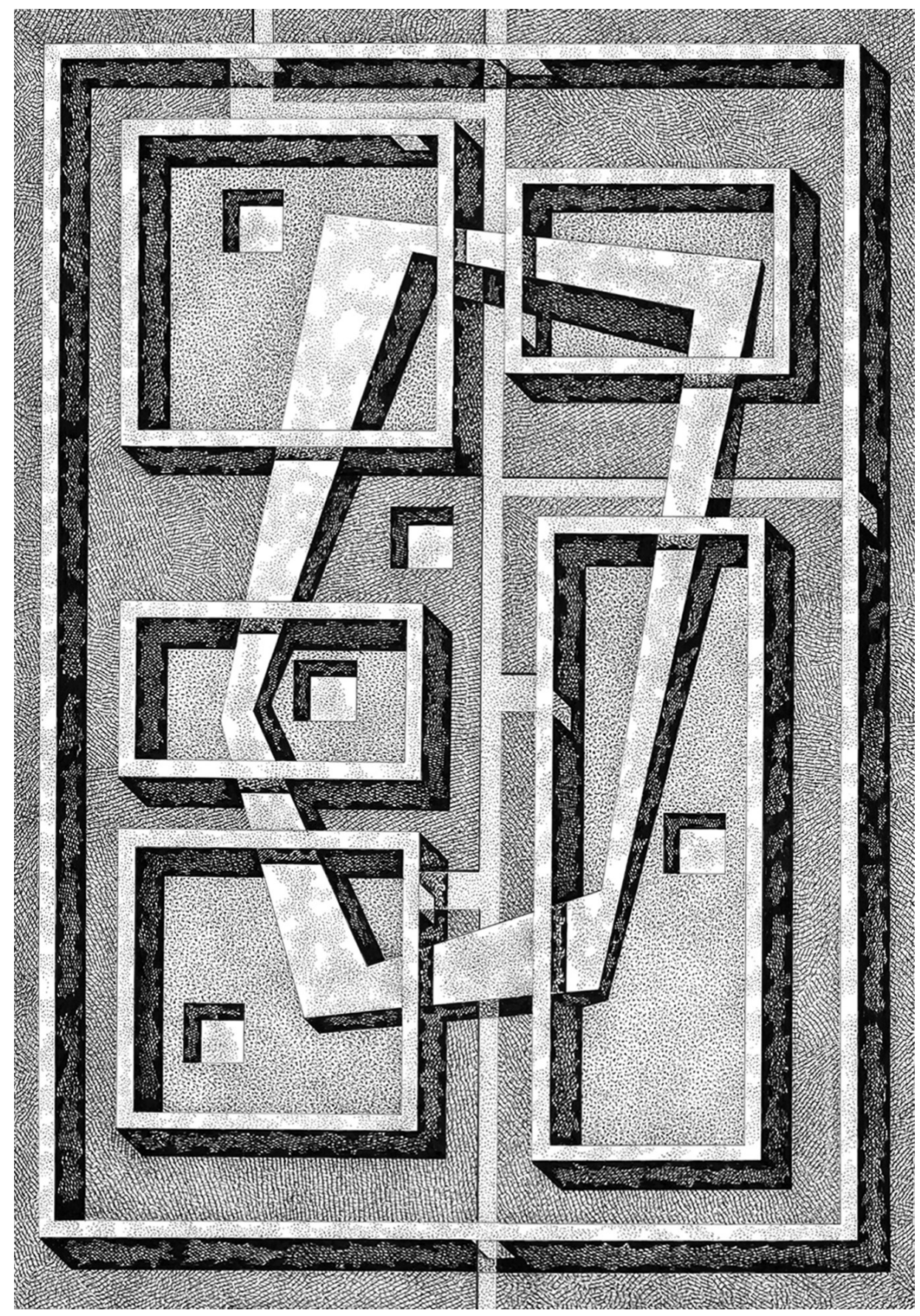




\section{Human beings have always been a migrant species}

Human beings have always been a migrant species[Pievani 2016]. For this reason, the massive displacements of populations which, in recent years, starting from the peripheries of the world (Afghanistan, Mexico, Syria, South Sudan, etc.), have moved and still continue to move towards large cities placing their trust in better life prospects cannot and should not be surprising. Not surprisingly, after the first humans moved from South Africa to North Africa about 200,000 years ago, and then, about 60,000 years ago, began colonising the globe venturing the tip of South America, repeated migratory phenomena followed [Cohen 2019; Sheller, Urry 2006]: from the barbarian invasions (166-476) to Mongolian transmigrations (1206-1259), from the Atlantic slave trade (I70|-I8I0) to transatlantic emigration from Europe to the United States of America (I8I5-19|4), from the exodus of the Irish population following the Great Hunger ( 1845 - 1 850) to the Jewish diaspora caused by the advent of the Nazi regime (1933-1940) and the dispersal of Vietnamese boat people throughout Southeast Asia (1975-1995). What may instead and should be surprising is the fact that recent migratory phenomena, instead of being interpreted as opportunities for social growth and urban renewal, have been rejected a priori and have been pointed to as the trigger of the identity crisis afflicting Europe [I]. However, history teaches us that it was precisely the great migrations of antiquity that levelled genetic differences allowing the formation of a single human species scattered all over the planet. Just as it teaches us that the beauty of European cities in general, and of Italian cities in particular, derives from their ability to virtuously govern the processes of integration and exchange between heterogeneous cultural components that have taken place over the centuries, including within its fabric the presence of multiple social communities, multiple spoken languages and multiple architectural styles which, mutually contaminating each other, have always reflected their civil multiplicity [Rossi 1978].

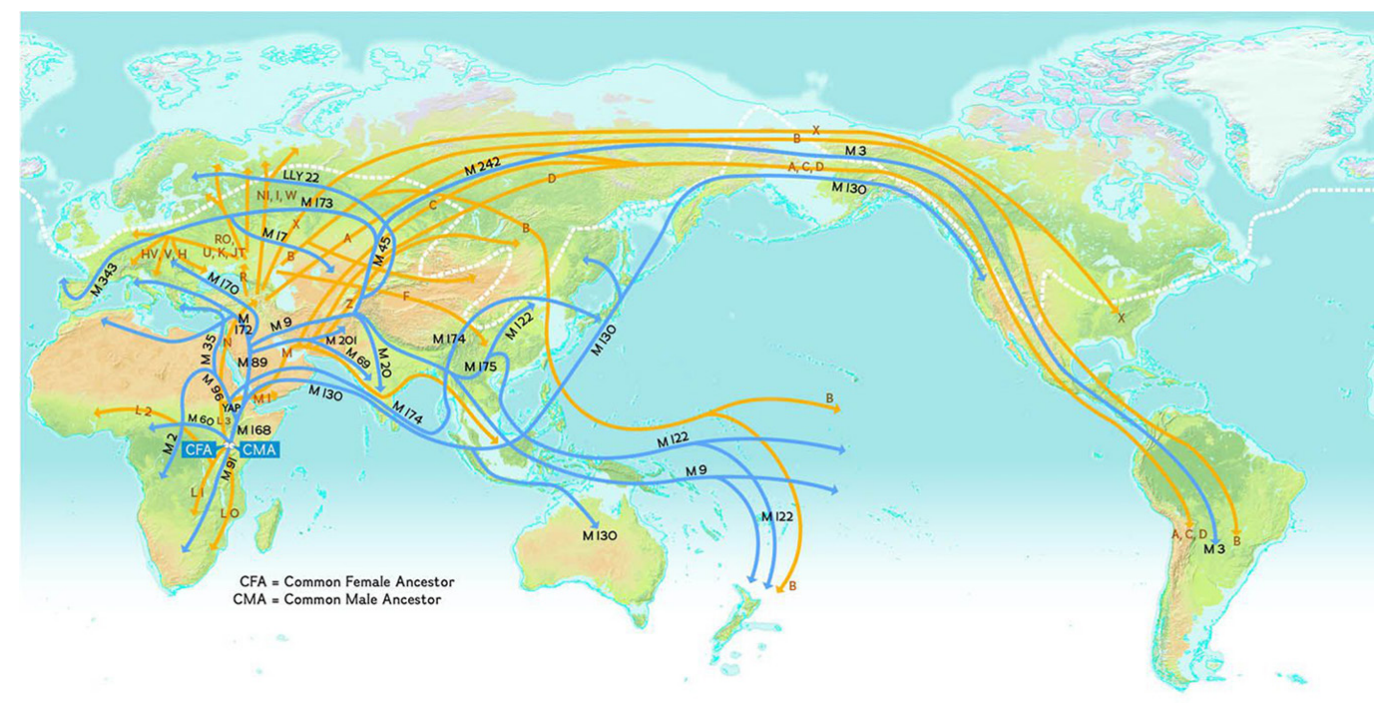

\section{Hospitality is one of the foundations of European civilisation}

Hospitality is one of the foundations of European civilisation. As evidenced at the linguistic level, given that "the root of the Latin word hospes is found in hostis (the foreigner who enjoys the same rights as the Roman people), in turn deriving from the Indo-European ghostis, from which host and guest in English, and gast in German, also derive" [Agostini 20 I7, p. 69]. To the extent that the Italian word 'ospite', indicating at the same time 'ospitato' (guest) and 'ospitante' (host), betrays the reciprocity of an always sacred pact of hospitality. In fact, it 
is known that in archaic civilisations the refusal of hospitality was considered a sacrilegious act, just as it is known that the Greeks believed that the gods could present themselves incognito as guests, distributing rewards or punishments based on the behaviour of the host. But it is equally known that, with the affirmation of Christianity as a state religion, welcoming of the poor and marginalised became a form of institutionalisation of the evangelical mandate, locked in a Borromeo knot with that of religious orders and pilgrimage routes. During the Middle Ages, 'xenodochia' and 'hospitalia' [Mazzi 2000; Beltramo, Cozzo 20I3; Franco 2017] (quadrangular buildings, organised around one or more internal courtyards, which found an expression completed in Ca' Granda, built in Milan in the second half of the fifteenth century based on a project by Filarete) consolidated along these routes. Standing out in the ranks of two extraordinarily innovative building typologies, chosen not by chance as "cathedrals of hospitality", which anticipated the enlightenment typology of the reclusors, and called on to welcome disadvantaged citizens, are the Albergo dei Poveri in Genoa, built to a design by Stefano Scaniglia, the Reale Albergo dei Poveri in Palermo, built to a design by Orazio Furetto then taken up by Giuseppe Venanzio Marvuglia and Nicolò Puglia, and the Reale Albergo dei Poveri in Naples, built only partially to a design by Ferdinando Fuga. But above all, the fundamental role played by hospitality in the formation of European cities can be found in the ability to deal with the housing emergencies that occurred over the centuries, changing their morphological rules according to the ethnic hybridisations induced by migratory flows. Moreover, always and in any case building in the built, even when it was a question of radically changing the most identifying monuments. Just think of the exemplary cases of the Roman amphitheatre of Nimes and the imperial palace of Split, converted into fortified citadels to welcome those persecuted by the punitive campaigns of Carlo Martello and the survivors of the Avari raids, respectively [2].

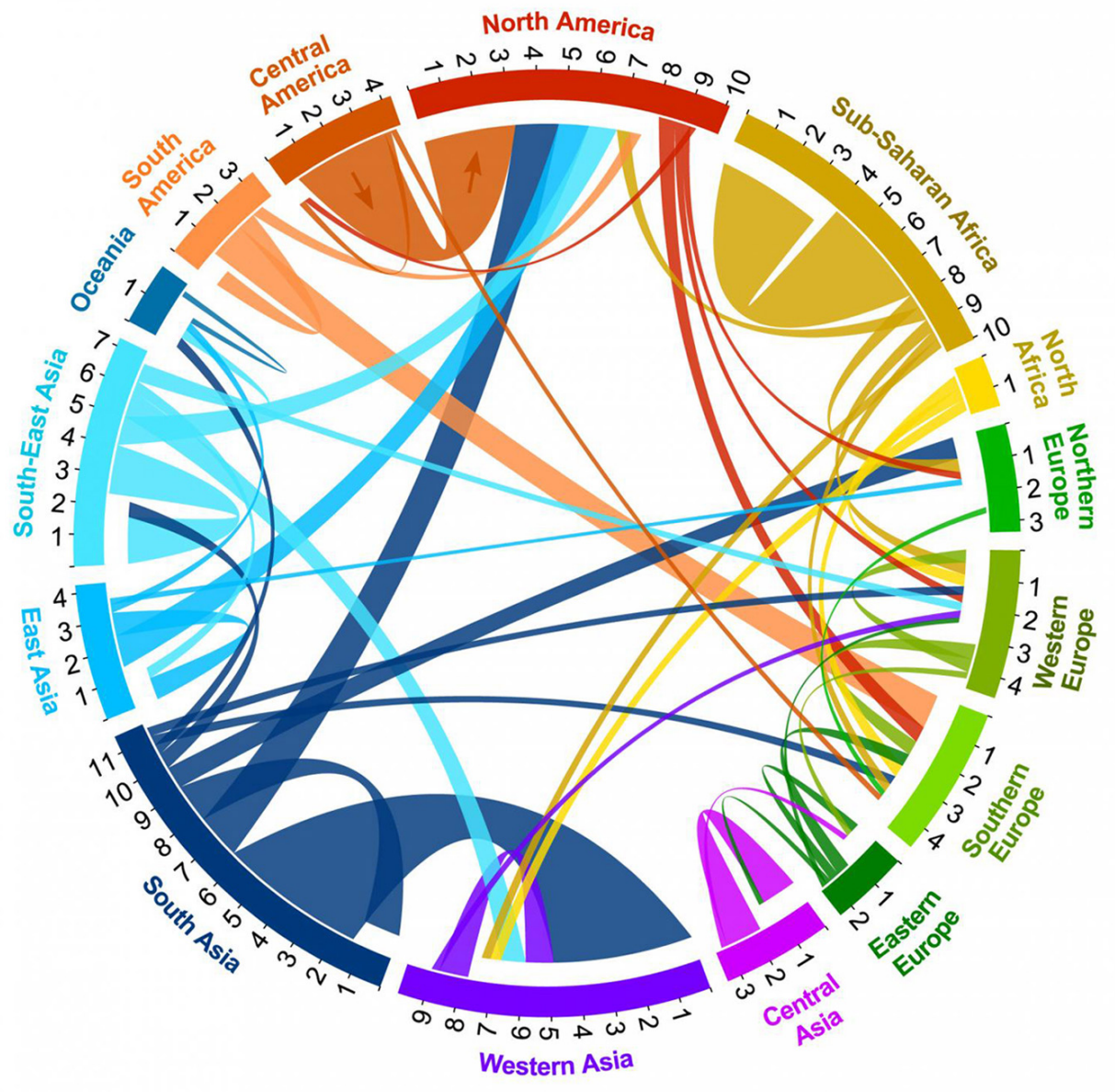




\section{In Europe, recent migratory flows have been marked by discontinuity}

In Europe, recent migratory flows have been marked by discontinuity [Melotti 2004; Bettin, Cela 2014]. To the extent that at least three phases are recognisable. The first phase (1945-1973) was marked by both intercontinental and continental migrations, where intercontinental migrations were induced by the 'expulsion factors' present in the countries of exodus, including the effects of the great political and economic crises that accompanied the process of decolonisation. On the other hand, in addition to the expulsion factors present in the countries of exodus (demographic, economic, social, cultural and partly political, as in the case of Spain, Portugal, Greece and Yugoslavia), continental migrations were induced by the attraction factors of the countries of destination, including the call from southern to northern Europe for cheap labour for post-war reconstruction. The second phase (19731982) began with the economic crisis triggered by the oil embargo and, alongside it, with exhaustion of the driving function of the production activities that had characterised the economic boom of the Sixties. In this phase, with continental migrations diminishing, the pressure of intercontinental migratory flows resumed, often and willingly clandestine because they originated in countries devastated by social tensions and even very bloody civil conflicts (from Argentina to Chile, from Ethiopia to Sri Lanka). The third phase (1982-2020) was started by economic recovery from the crisis of the Seventies and, albeit amid the ups and downs of the economic situation and the impact of historic historical events (from the collapse of the Berlin Wall to the attacks on the Twin Towers of New York and the economic crisis that began in 2008), is still ongoing and is marked by an intensification of migratory flows attributable to the expulsion factors of the countries of exodus. Above all in Africa where, with the hopes and illusions of decolonisation and political independence having disappeared, economic crisis and social disintegration have occurred which, rendered cruel by extremely bloody conflicts, are driving growing masses of young people to flee, willing to face every risk just to escape a life without prospects. This is confirmed by the continuous tragedies that afflict those who try to first cross the Sahara Desert and then the Mediterranean sea with inadequate means of transport -because they are old and overcrowded, as well as outlawed- operated by real criminal organisations.

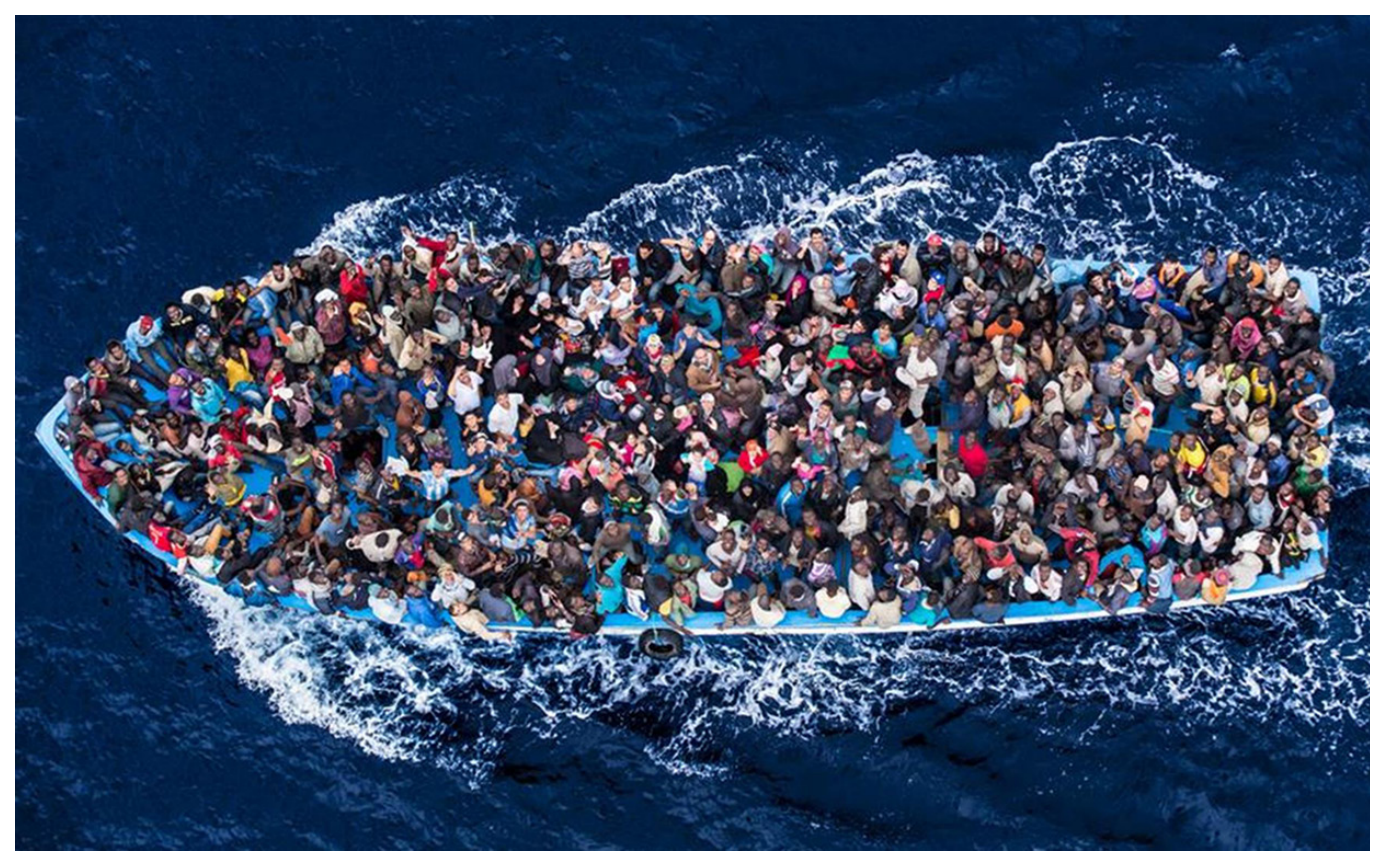




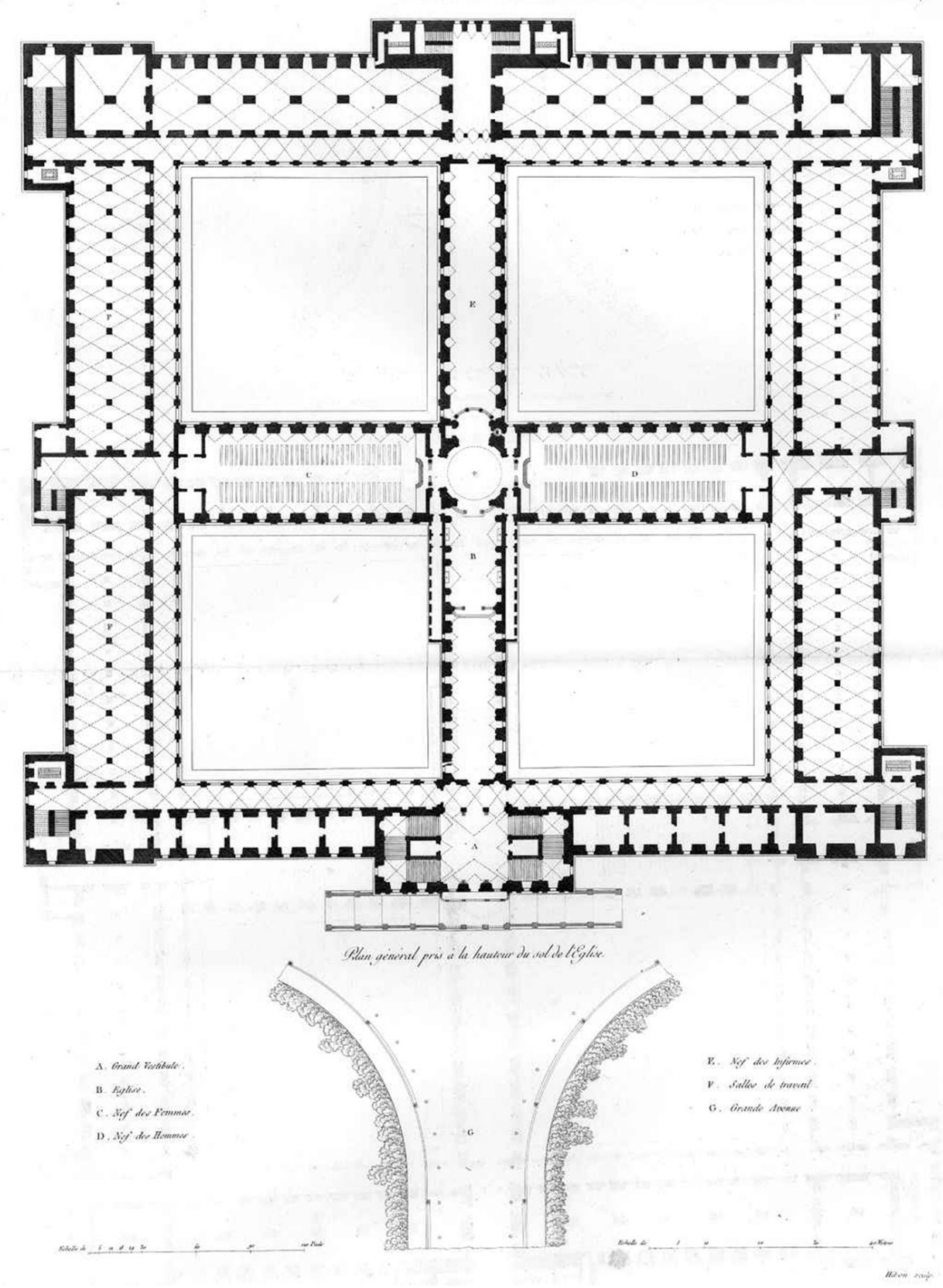




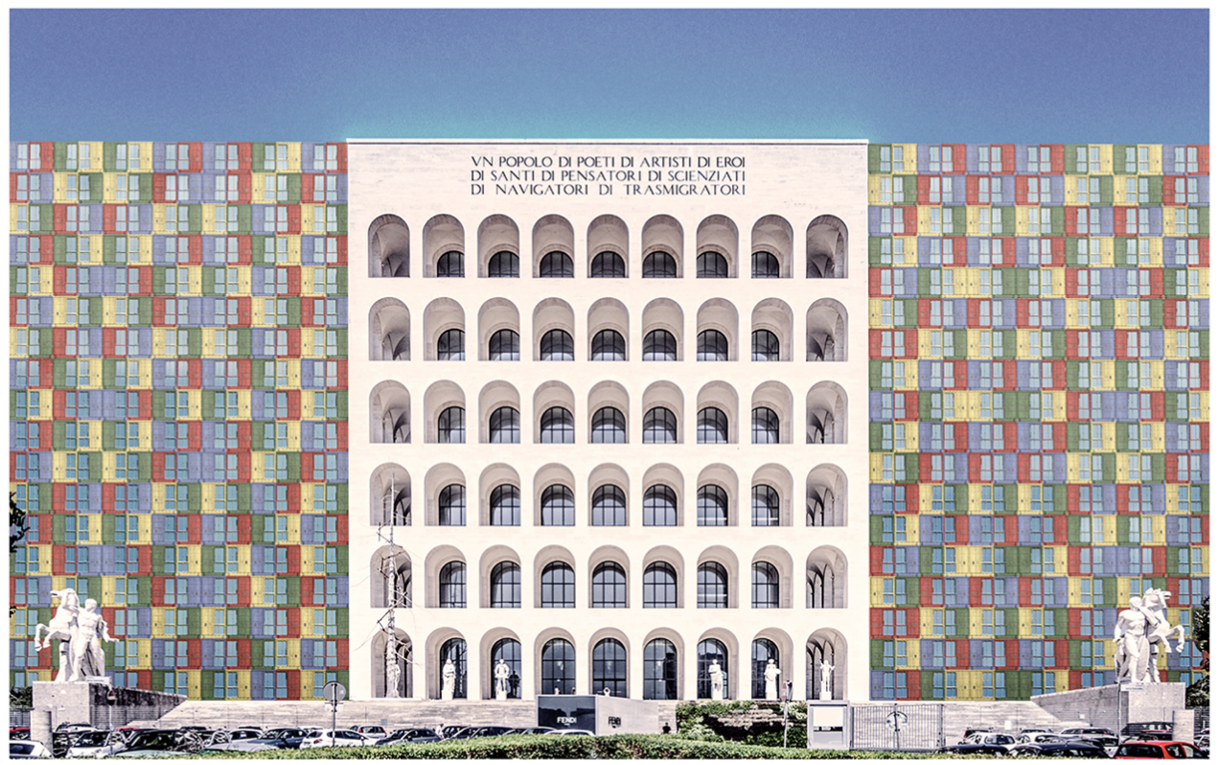

saluti da Rama

\section{Sounenir d'Italie}

ROMA - EUR - VILLAGGIO DELL'ACCOGLIENZA

Machere Pauline,
je suis retourne en Palie apris beaucoup diannées
et j'ai éte fascine par la créativite et la genirosite avec lesquelles limergence d accucillir nos fieres immigrants a éte resolve, en donnant vie aux villes les plus inclusives quejaic jamais vnes... Aliles Aaliens!

$$
\text { ton Bernard }
$$

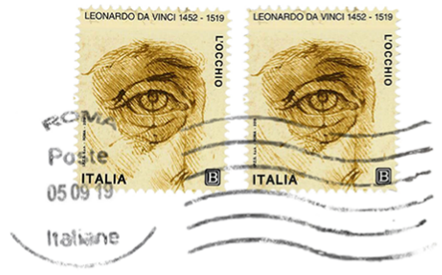

Pauline Piop
$\frac{\text { 23. we de la Republique }}{12500 \text { - Dakar }}$
Senegal 
Fig. 7. Souvenir d'Italie: Verona, Caserta, Mila

Fig. 8. Souvenir d'Italie: Venezia, Matera, Firenze Salemi, Hoflab, 2019
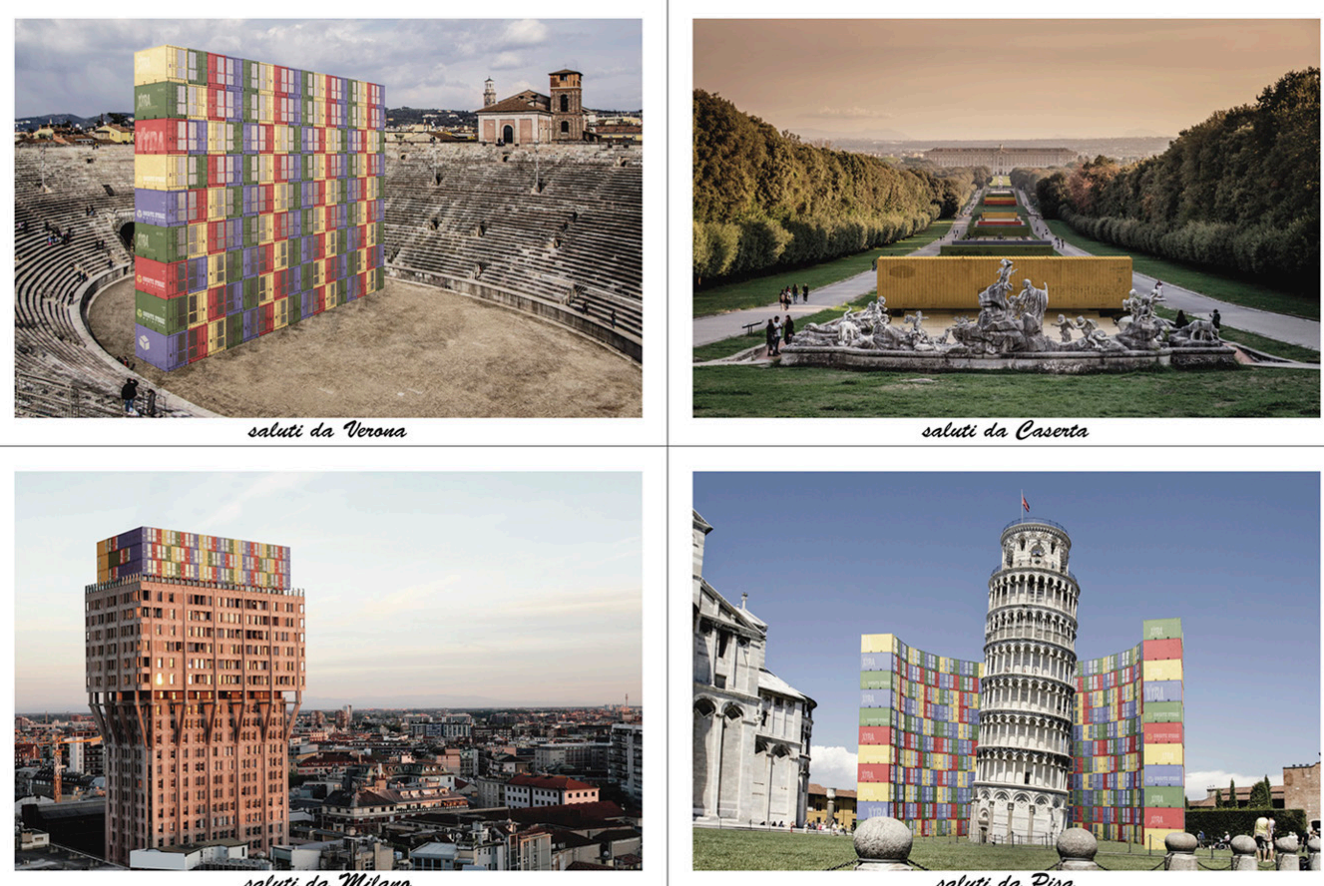

saluti da Milana
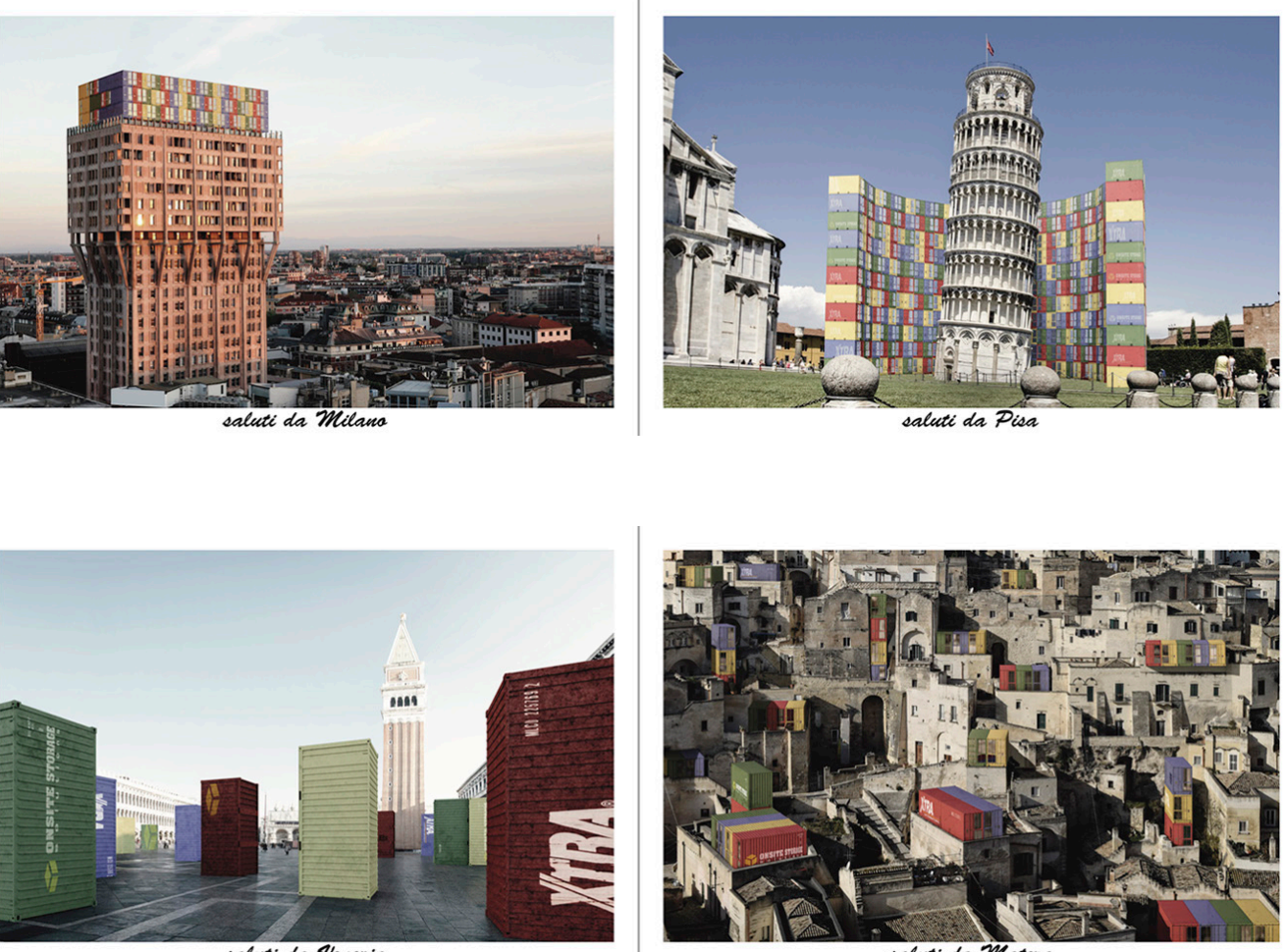

saluti da Venezia

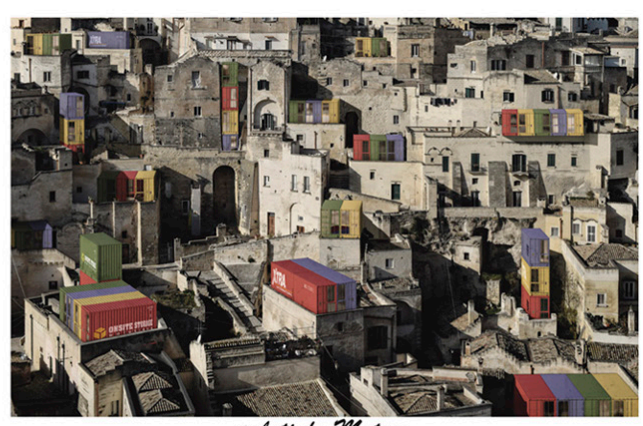

saluti da Matera
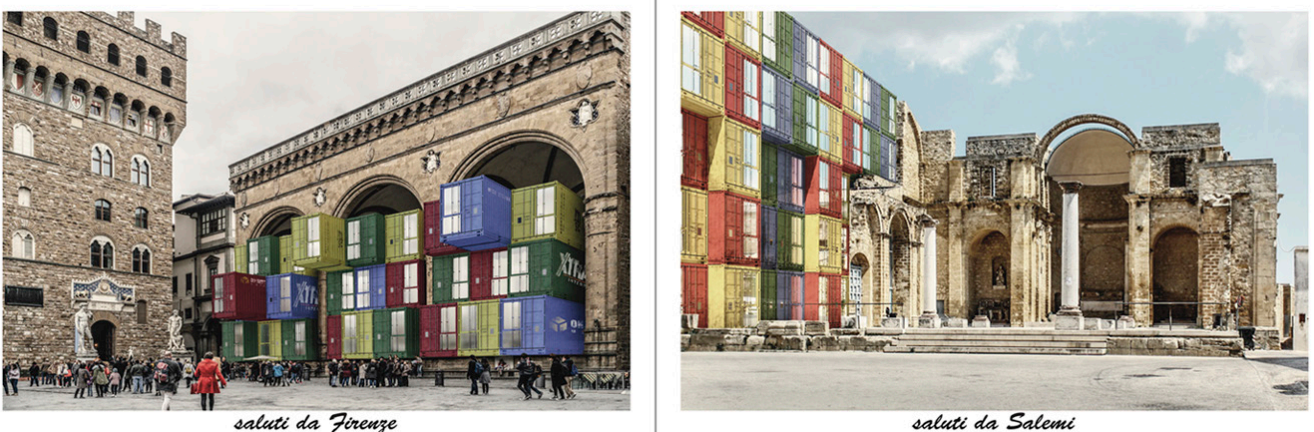


\section{Migratory flows have always generated new spaces}

Migratory flows have always generated new spaces. Or at least they have generated the rethinking of existing spaces by introducing the fruitful germs of an alternative housing culture. Also, and especially in Italy[Abdelmalek 2002; De Maria, Lagravinese 20I5; Cossu 20I8-20I9, p. 28; De Micco 20I6-20 I7]. In fact, it is evident that, while integration is an ambivalent and multidimensional concept involving anthropological, cultural, economic and social aspects, it is precisely housing integration that involves the most complex and therefore most demanding problems. This is because the high percentage of illegal immigrants encourages the proliferation of real ghettos in which a large part of the low-cost labour force employed in agriculture in seasonal processing and harvesting activities is segregated. This is because the areas in which regular immigrants tend to converge, also as a result of the discrimination that orients the property market, are mostly marginal and have some common characteristics in that they are formed in parts degraded and abandoned by the natives, in which the cost of housing is very low, and they are often places in which it is possible to shape abandoned space according to one's own way of life. The result is a phenomenon of housing exclusion which locks the concept of integration with that of equal opportunities into one and which feeds a parallel market, made up of a property portfolio consisting of buildings otherwise uninhabitable according to relevant Italian legislation [Tosi 2000, p. 320; Tosi 1994]. Based on recommendations issued by the Protection System for Asylum Seekers and Refugees (SPRAR) established by the Ministry of the Interior of the Italian Republic, hospitality facilities, "must in any case be in possession of the requirements laid

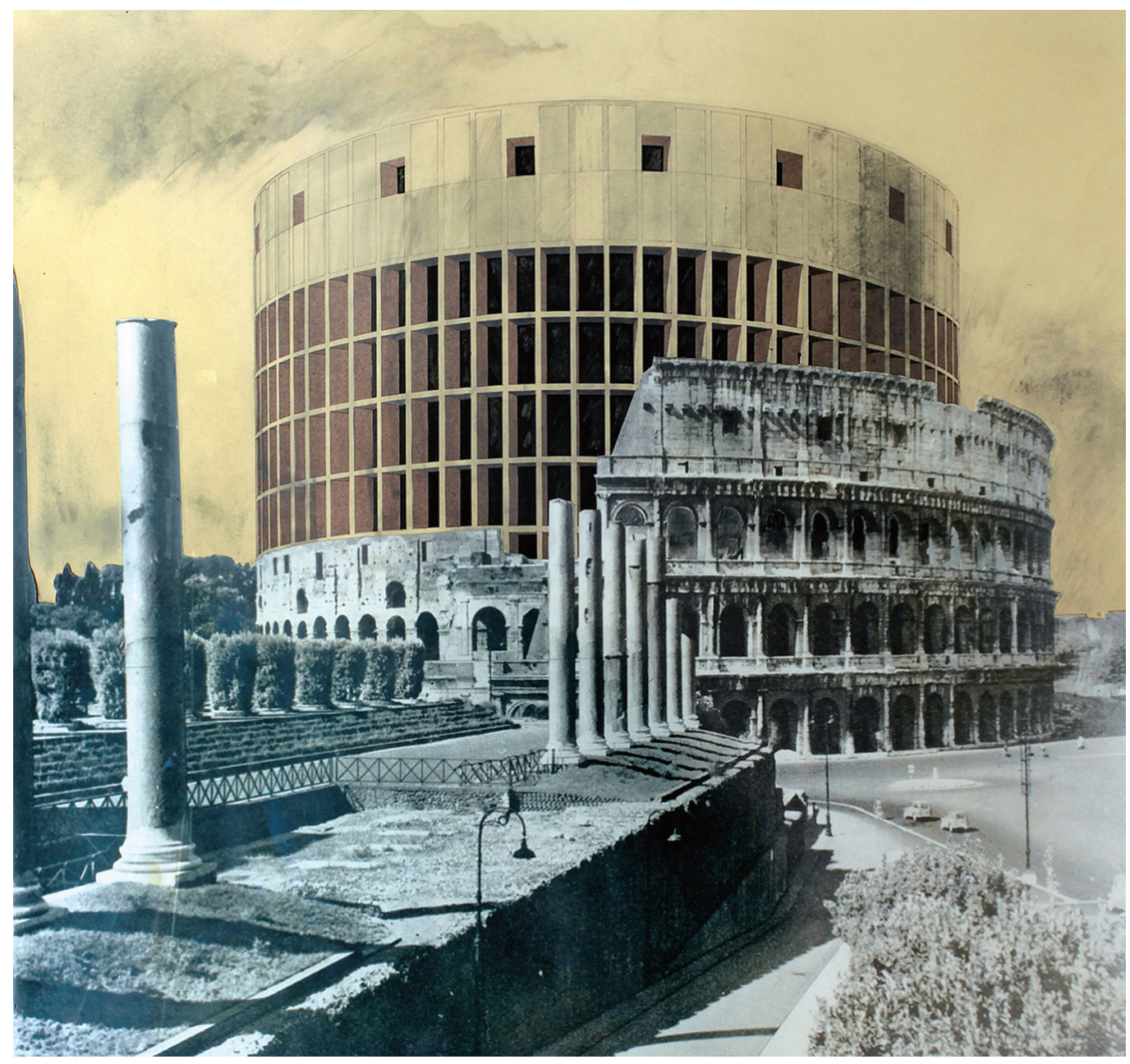


down by current regulations on town planning, building, fire prevention, hygiene and safety $[\ldots]$. The hospitality facility must be equipped with adequate and sufficient toilets in relation to the beneficiaries housed (minimum I every 6), as well as proportionally higher based on the number of beneficiaries and the presence of mixed genders. The rooms -always with windows open to the outside- must be proportional to the number of people housed (maximum 4 people per room in collective centres; 2 or 3 people in apartments). But above all, in order not to hinder participation in social life and access to local services by beneficiaries, it is important that the hospitality facility is located in inhabited places, easily accessible by public transport services" [SPRAR 20 I 8, pp. 32, 33].

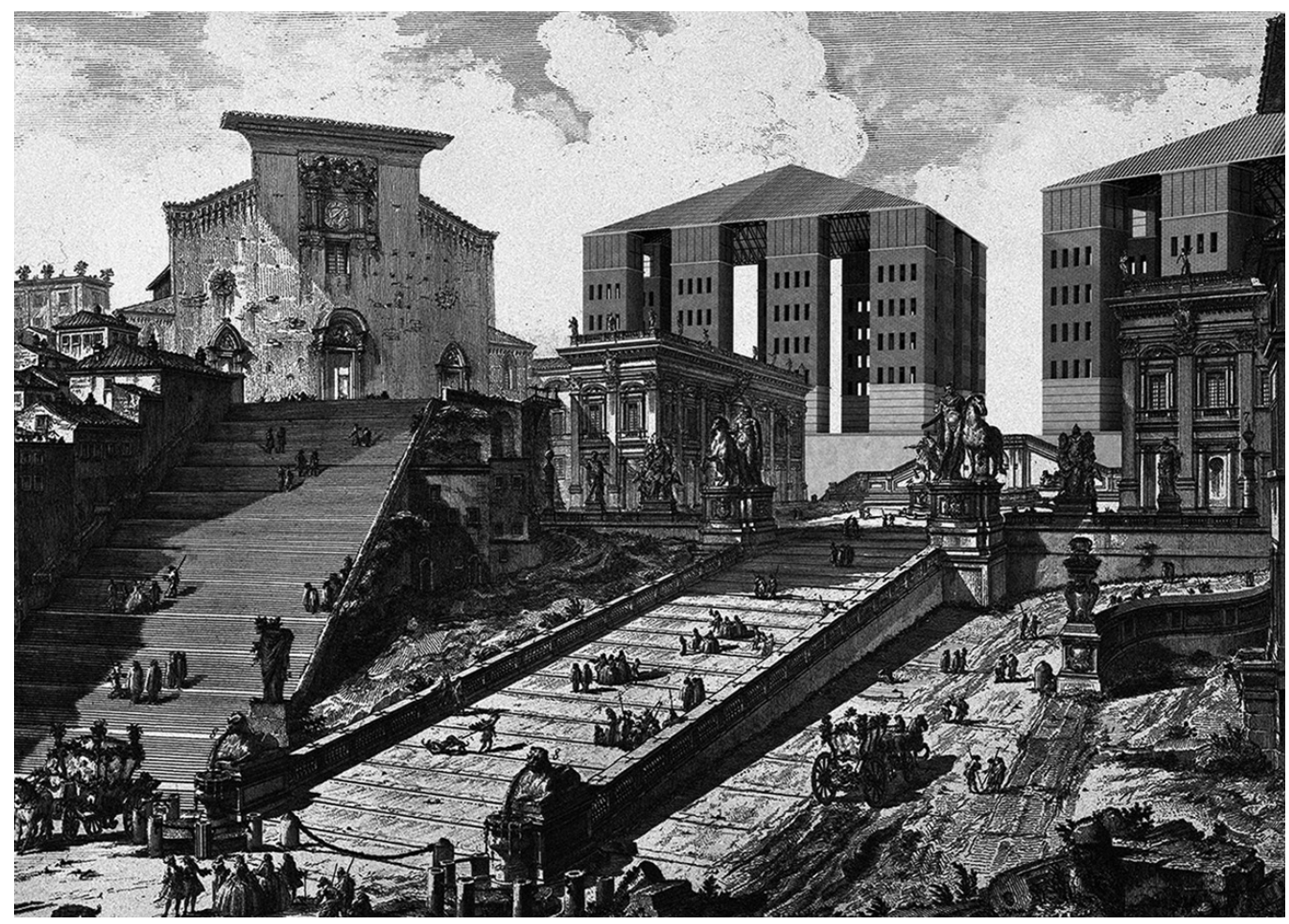

In the future Italy will be a multiracial or, if you prefer, coloured country

In the future Italy will be a multiracial or, if you prefer, coloured country. Like Europe [Eco 2017, p. 26]. Precisely because we Italians live in cities that have evolved in the sign of continuity, we are particularly predisposed to conceiving new, albeit transitory, housing models aimed at welcoming immigrant populations (regardless of whether they are migrants or refugees), building above, below, inside, around and alongside existing structures. This is the meaning of the Souvenir d'Italie project, presented by Hoflab as part of the La città dell'inclusione (The City of Inclusion) project, held in Rome in the space of the MACRO Asilo from $9^{\text {th }}$ to $10^{\text {th }}$ November 2019, in which nine possible housing solutions for hospitality are prefigured, illustrated in the form of tourist postcards and marked by the grafting of authentic pop-up villages onto the most identifiable monuments of our country: from the Arena of Verona to the Palace of Caserta, from the Velasca Tower of Milan to the Leaning Tower of Pisa, from St. Mark's Square in Venice to the Sassi district of Matera, from the Loggia dei Lanzi in Florence to the former Chiesa Madre of Salemi. Up to the Civiltà del Lavoro building in Rome, embedded between two super-condominiums composed with an 


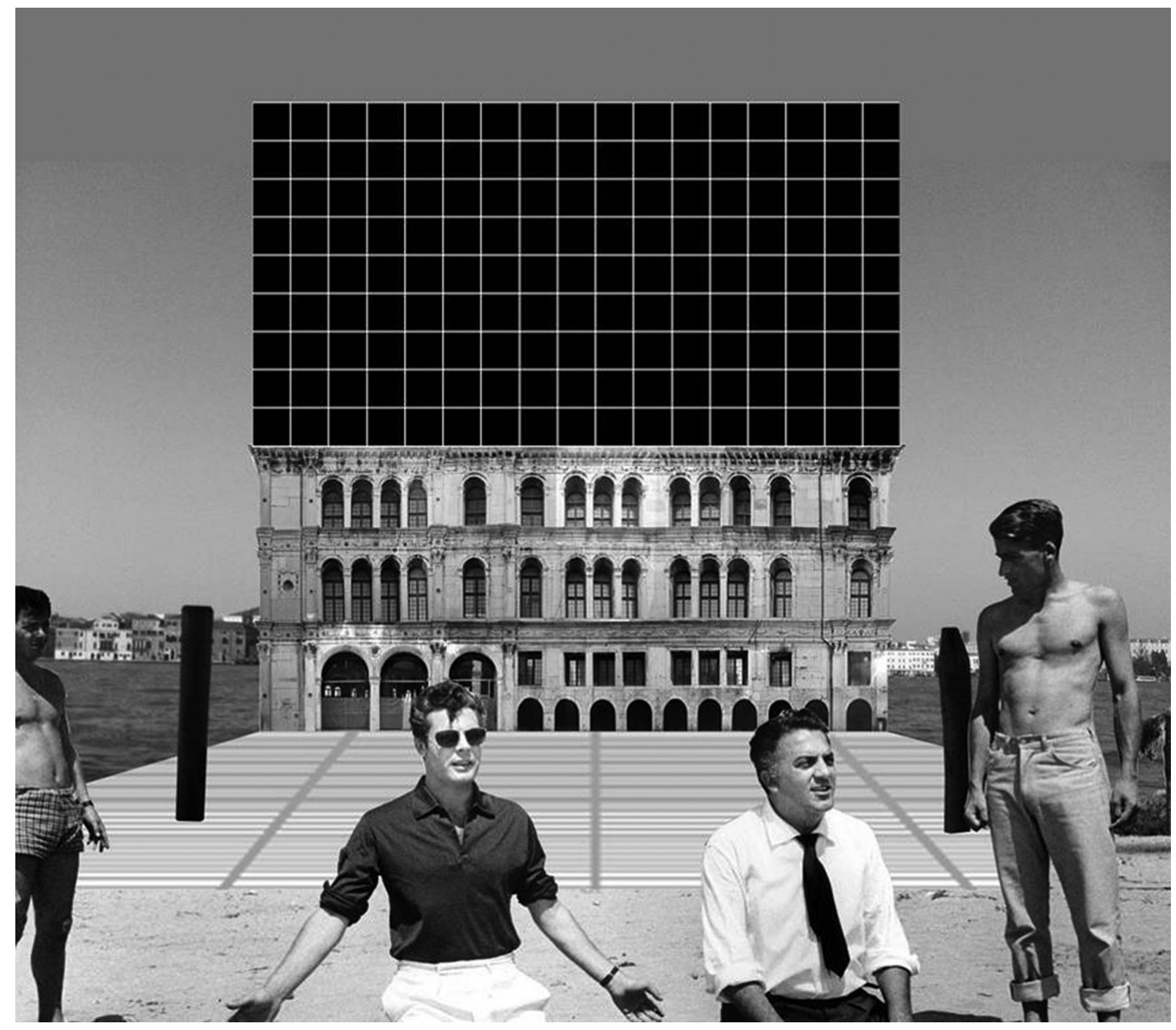

Fig. 12. Supernapoli,

Cherubino Gambardella,

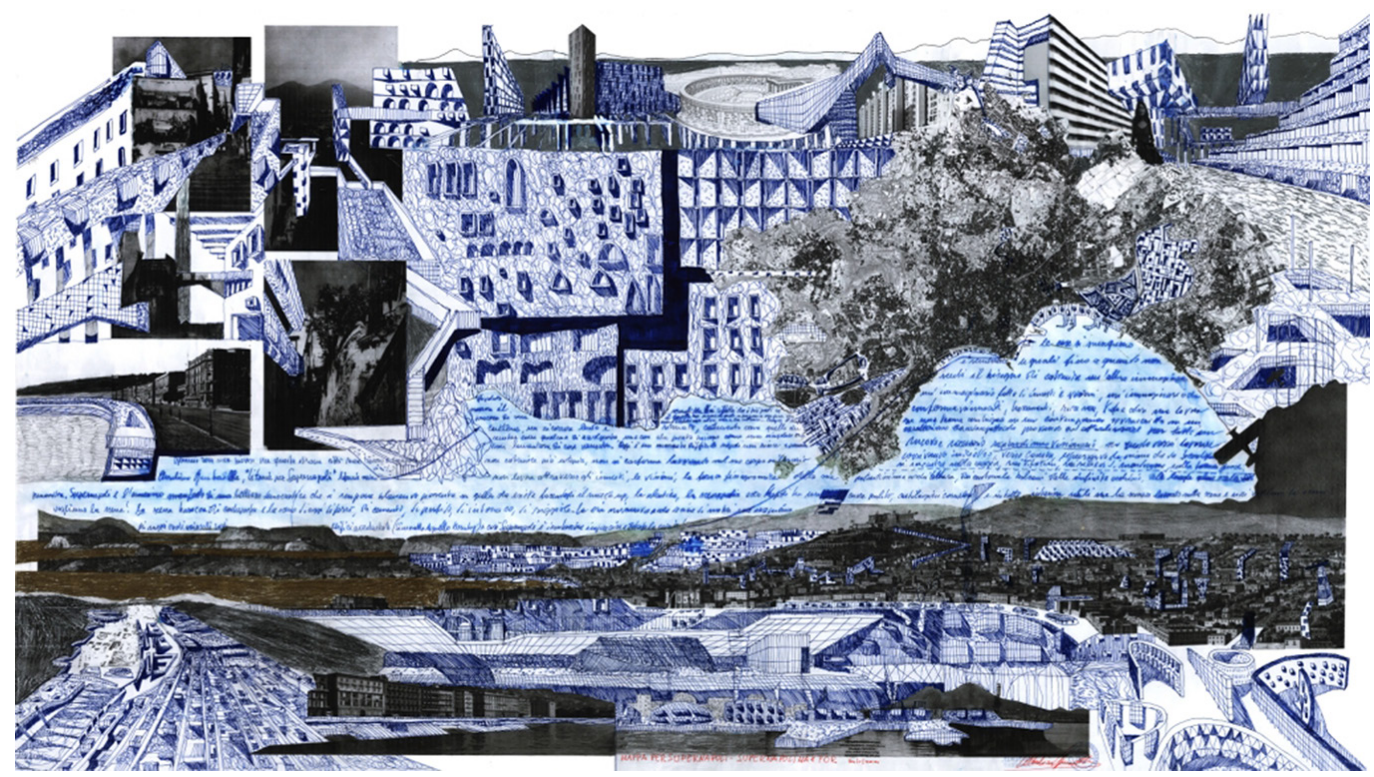


iteration of polychrome containers: a typological solution so bold as to stun Bernard, the imaginary French artist who, struck by so much creativity (as well as so much generosity), writes a postcard to his Senegalese wife on the spot. "Ma chère Pauline, je suis retourné en Italie après beaucoup d'années et j'ai été fasciné par la créativité et la générosité avec lesquelles l'émergence d'accueillir nos freres immigrants a été résolue, en donnant vie aux villes les plus inclusives que j'aie jamais vues ... Ah, les Italiens!' [Hoflab 20 19, p. 43] Nine surprising typological solutions, which evoke themost picturesque architecture of our cities (from the Savelli family home, built on the remains of the Roman theatre of Marcello, to the fishermen's houses of Atrani, wedged in the arches of the Bourbon coastal road) and which are conveyed through as many infographic simulations; with programmatic provocative intent, these are aimed at claiming the inclusive vocation of visionary drawing, even in the most intricate cases such as Italian historical centres in general and the historical centre of Rome in particular (from Grand Hotel Colosseo by Superstudio to View of Piazza del Campidoglio by Leon Krier, from Palazzo Veneziano by Carmelo Baglivo to Supernapoli by Cherubino Gambardella). On the other hand, as clearly recorded by Franco Purini, to include means "to insert a certain number of similar or different elements into each other [...] -which-creates an organic system of interrelationships and interferences" [Purini 2019, p. 94]: as much in the architectural drawing as in the architecture of the city. In other words, it means giving back to utopia its right to exist, through the practice of visionary drawing.

\section{Notes}

[I] "Integration must be a mutual exchange of human experience on a psychological level, it must be a cultural exchange from which a broader and more mature perspective emerges and it must be an insertion of the immigrant in the new social structure as a vital and functional part that enriches the whole" [Alberoni, Baglioni 1965, p. 26. See also Hoerder 2002; Hatton, Williamson 2005]

[2] "But at the urban level I have not illustrated the case of Split here, which in my opinion constitutes, not an exceptional example, but certainly the most probable. That is, that of a large building, a palace, which becomes a city and transforms its internal characters into urban characters, demonstrating the infinite richness of analogical transformations in architecture when it operates on precise forms" [Rossi 1978, p. 244].

\section{References}

Abdelmalek Sayad (2002). La doppia assenza. Dalle illusioni dell'emigrato alle sofferenze dell'immigrato. Milano: Raffaello Cortina.

Agostini llaria (2017). Per civica pietà. Architettura dell'accoglienza nella città medievale (V-XV secolo). In Agostini llaria, Attili Giovanna, Decandia Lidia et al. La città e l'accoglienza. Castel San Pietro Romano (Rm): La Talpa, pp. 69-98.

Alberoni Francesco, Baglioni Guido (1965). L'integrazione dellimmigrato nella società industriale. Bologna: II Mulino.

Beltramo Silvia, Cozzo Paolo (a cura di). (20/3). L'accoglienza religiosa tra tardo antico ed età moderna: luoghi, architetture, percorsi. Roma:Viella Libreria Editrice.

Bettin Giulia, Cela Eralba (20 I4). L'evoluzione storica dei flussi migratori in Europa e in Italia. Venezia: Università IUAV di Venezia.

Bonifazi Corrado (2007). L'immigrazione straniera in Italia. Bologna: II Mulino.

Cohen Robin (2019). Migration. London: André Deutsch Limited.

Colombo Asher, Sciortino Giuseppe (a cura di). (2002). Stranieri in Italia: assimilati ed esclusi. Bologna: II Mulino.

Colombo Asher, Sciortino Giuseppe (2004). Gli immigrati in Italia. Bologna: II Mulino.

Cossu Edoardo (2018-2019). Spaces for Migrant Reception in the Municipalities of Basso Campidano. Torino: Politecnico di Torino. Decimo Francesca, Sciortino Giuseppe (a cura di). (2006). Reti migranti. Bologna: II Mulino.

De Maria Marcello, Lagravinese Raffaele (2015). II disagio abitativo dei migranti in Italia. Best practices per una società migliore. Bari: Università degli Studi di Bari Aldo Moro.

De Micco Lorenzo Emilio (2016-20 17). Architettura dell'accoglienza. Le implicazioni spaziali della crisi migratoria raccontati attraverso la digital fabbrication. Milano: Politecnico di Milano.

Eco Umberto (2019). Migrazioni e intolleranza. Milano: La nave di Teseo.

Franco Elena (2017). Hospitalia o sul significato della cura.Torino: Artema.

Hatton Timothy J., Williamson Jeffrey G. (2005). Global Migration and the World Economy. Cambridge USA: MIT Press. 
Hoerder Dirk (2002). Cultures in Contact. Durham USA: Duke University Press.

Hoflab (2019). Souvenir d'Italie. In Messina Francesco, Zerella Laura (a cura di). La città dell'inclusione. Spoleto (Pg): ADD-art, pp. $42,43$.

Mazzi Maria Serena (2000). I viaggi dei poveri e degli emarginati. In Gensini Sergio (a cura di). Viaggiare nel Medioevo. Ospedaletto (Pi): Pacini Editore, pp. 317-336.

Melotti Umberto (1994). L'immigrazione in Italia: da modello senza progetto a progetto senza modello. Un confronto con altri paesi europei. In Annali di Sociologia/Soziologisches Jahrbuch, 10, 1994, pp. 2 I I-232.

Melotti Umberto (2004). Migrazioni internazionali: globalizzazione e culture politiche. Milano: Bruno Mondadori Editore.

Natale Marcello, Strozza Salvatore (1997). Gli immigrati stranieri in Italia. Quanti sono, chi sono, come vivono?. Bari: Cacucci.

Pievani Telmo (20 I6). Migranti, da due milioni di anni. In Micron, n. 34, pp. 2 I-25.

Pugliese Enrico (2002). L'Italia tra migrazioni internazionali e migrazioni interne. Bologna: II Mulino.

Purini Franco (2019). Includere. In Messina Francesco, Zerella Laura (a cura di). La città dell'inclusione. Spoleto (Pg): ADD-art, 2019 , pp. 94, 95

Rossi Aldo (1978). L'architettura della città. Milano: Clup.

Sheller Mimi, Urry John (2006). The new mobilities paradigm. In Environment and Planning A: Economy and Space, n. 38, pp. 207-226.

SPRAR (20 I 8). Manuale operativo per l'attivazione e la gestione di servizi di accoglienza e integrazione per richiedenti e titolari di protezione internazionale e umanitaria. Roma: Ministero dell'Interno Italiano.

Tosi Antonio (1994). Abitare/coabitare. Gli immigrati extracomunitari e le politiche abitative in Italia. In Tosi Antonio (a cura di). Abitanti. Le nuove strategie dell'azione abitativa. Bologna: II Mulino, pp. 29-40.

Tosi Antonio (2000). Casa e immigrazione. In Zincone Giovanna (a cura di). Primo rapporto sull'integrazione degli immigrati in Italia. Bologna: II Mulino, pp. 317-354.

\section{Author}

Paolo Belardi, Università degli Studi di Perugia, paolo.belardi@unipg.it

To cite this chapter. Belardi Paolo (2020). Souvenir d'Italie. La vocazione inclusiva del disegno visionario/Souvenir d'Italie. The Inclusive Vocation of Visionary Drawing. In Arena A., Arena M., Brandolino R.G., Colistra D., Ginex G., Mediati D., Nucifora S., Raffa P. (a cura di). Connettere. Un disegno per annodare e tessere. Atti del $42^{\circ}$ Convegno Internazionale dei Docenti delle Discipline della Rappresentazione/Connecting. Drawing for weaving relationships. Proceedings of the 42th International Conference of Representation Disciplines Teachers. Milano: FrancoAngeli, pp. 889-914. 